\title{
OKANOGAN BASIN SPRING SPAWNER REPORT FOR 2007
}
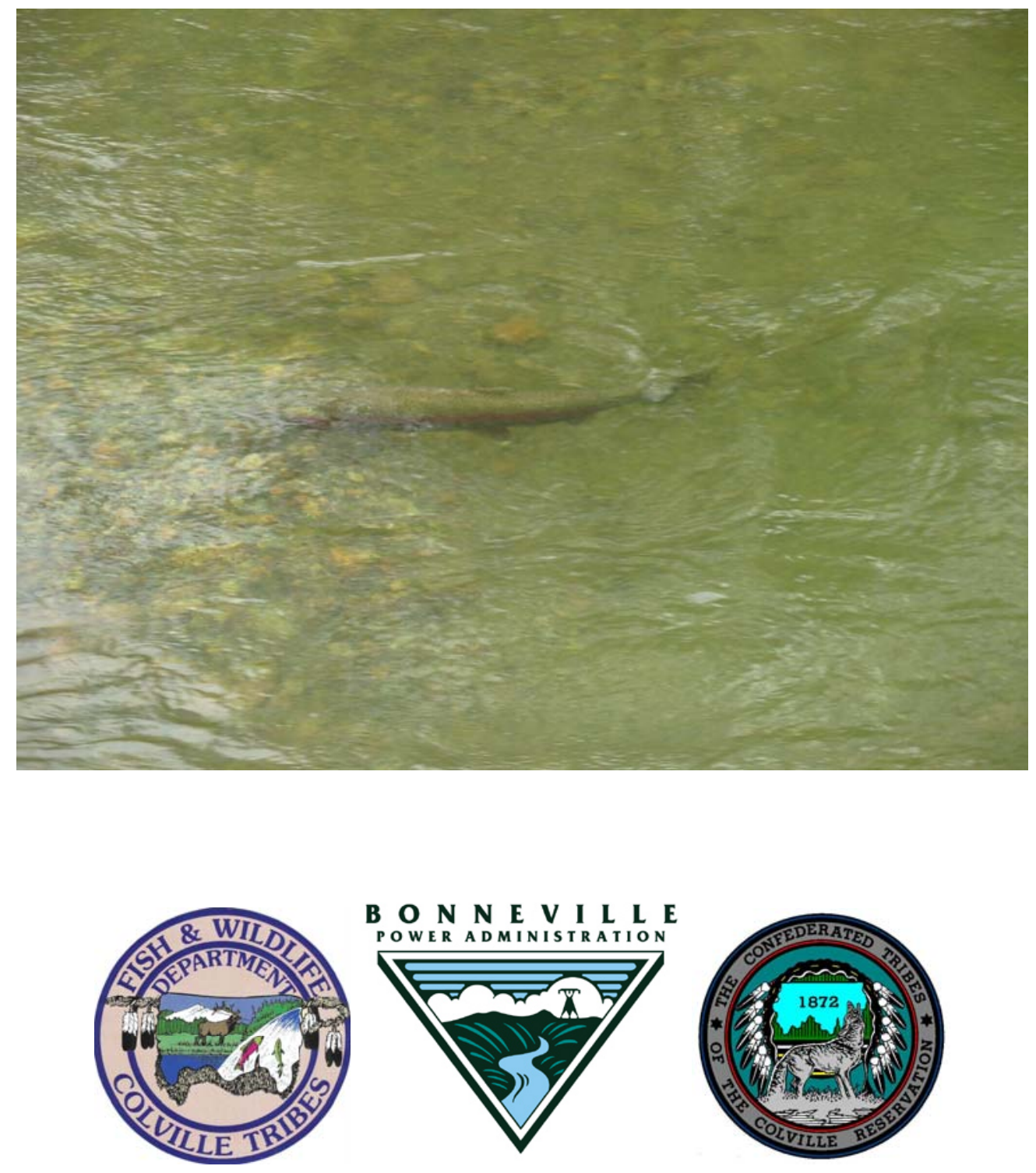

CCT/AF-2007-6

COLVILLE TRIBES

September 2007

\section{DEPARTMENT OF FISH \& WILDLIFE} ANADROMOUS FISH DIVISION-OMAK OFFICE

23 Brooks Tracts Road, Omak WA 98841

Voice (509) 422-7424 Fax (509) 422-7428 


\section{OKANOGAN BASIN SPRING SPAWNER REPORT FOR 2007}

Performance Period: March 1, 2007 - February 28, 2008

CCT Account \# 315807

BPA Project \# 200302200

Prepared by

John Arterburn, Keith Kistler, Chris Fisher, and Michael Rayton

Prepared for

U.S. Department of Energy

Bonneville Power Administration

Division of Fish and Wildlife

P.O. Box 3621

Portland, OR 97208-3621

\section{September 2007}




\title{
Acknowledgement
}

The authors of this document and the Anadromous Fish Division of the Colville Tribes Fish and Wildlife Department would like to thank the following people for help in collecting or compiling data used in this report; Edward Berrigan, Charlie Snow, Bob Jateff, Tim Erb, Jr., and Rhonda Dasher. We would also like to thank all the people involved with administrating contracts for, and funding of, the Okanogan Basin Monitoring and Evaluation Program (BPA project number 2003-22-00).

\begin{abstract}
The Okanogan Basin Monitoring and Evaluation Program collected data related to spring spawning anadromous salmonid stocks across the entire Okanogan River basin. Data were collected using redd surveys, traps, underwater video, and PIT-tag technology then summarized and analyzed using simple estimate models. From these efforts we estimated that 1,266 summer steelhead spawned in the Okanogan River basin and constructed 552 redds; 152 of these fish where of natural origin. Of these, 121 summer steelhead, including 29 of natural origin, created an estimated 70 redds in the Canadian portion of the Okanagan basin. We estimated summer steelhead spawner escapement into each subwatershed along with the number from natural origin and the number and density of redds. We documented redd desiccation in Loup Loup Creek, habitat utilization in Salmon Creek as a result of a new water lease program, and 10 spring Chinook returning to Omak Creek. High water through most of the redd survey period resulted in development of new modeling techniques and allowed us to survey additional tributaries including the observation of summer steelhead spawning in Wanacut Creek. These 2007 data provide additional support that redd surveys conducted within the United States are well founded and provide essential information for tracking the recovery of listed summer steelhead. Conversely, redd surveys do not appear to be the best approach for enumerating steelhead spawners or there distribution within Canada. We also identified that spawning distributions within the Okanogan River basin vary widely and stocking location may play an over riding roll in this variability.
\end{abstract}

\section{Introduction}

The Okanogan Basin Monitoring and Evaluation Program (OBMEP) was created in March of 2004 to conduct basin-wide monitoring for anadromous fish in the Okanogan River basin. The OBMEP project is funded by the Bonneville Power Administration (BPA project \# 200302200) to fill data gaps particularly associated with endangered summer steelhead through implementation of scientifically rigorous, long-term status and trend monitoring of habitat, water quality, and biological indicators. OBMEP uses protocols derived from the Upper Columbia Strategy (Hillman 2006) that recommends one of the following: a) a complete redd census, if possible, or; b), an annual count of the number of redds within already-established index areas, or; c) an annual count of redds in randomly-selected reaches chosen using the EMAP design. By following the Upper Columbia Strategies we maintain coordination and compatibility with other monitoring 
and evaluation efforts in the Upper Columbia ESU, located in the Wenatchee, Entiat, Methow, Okanogan and main stem Columbia rivers above Priest Rapids Dam (Figure 1).

In 2005, a complete census of all main stem habitats was conducted within the U.S. for the first time. Several large areas contained no redds and were designated as unlikely to ever have suitable habitat for spawning to occur. Eliminating these areas from future surveys reduces cost without the loss of any biologically important data. A few other areas such as Tunk and Ninemile creeks have limited access due to a lack of land owner permission. Historic redd survey data collected by the Colville Tribes also provided important information used to establish reference reaches on Omak Creek. Collectively, several recommendations were made in 2005 that we first applied in 2006 and maintained in 2007. One such recommendation was limiting our main stem redd surveys to discharges less than 3,000 CFS due to poor visibility.

This is the third year of steelhead redd surveys conducted by the Colville Tribes in the Okanogan Basin. The 2005 report contained an extensive literature review of historic spawning information related to the Okanogan River basin (Arterburn et al. 2005). This document builds upon previously reported information. Previous annual survey reports can be accessed through our web-site at: http://nrd.colvilletribes.com/obmep/Reports.htm

\section{Methods}

Steelhead redd surveys were conducted in the Okanogan River and Similkameen River drainages, along the main stems and in all accessible tributaries downstream of identified anadromous fish migration barriers (Arterburn et al. 2007a, Walsh and Long 2006).

Designated main stem and tributary survey reaches have been defined and can be viewed in Table 1. These survey reaches encompass all known spawning habitat currently available in the United States portion of the Okanogan River basin (except parts of Tunk and Ninemile creeks) and are also include the majority of the annual and rotating panel EMAP habitat sites (Figure 2). The area of the Okanogan below the Chiliwist Creek confluence are subject to inundation from the Columbia River (Wells Pool/Lake Pateros) and therefore lacks the appropriate velocity and substrate needed for summer steelhead to spawn. We do not consider this area spawning habitat and therefore have eliminated it from any surveys or estimates.

Redd surveys were planned along the main stem Okanogan River between April 3 and May 1, 2007, and were to be conducted up to three times during the spawning period provided discharge levels in Okanogan River were below 3,000 cfs. However, discharge levels remained above 3,000 cfs for most of the redd survey period in 2007 which limited our surveys to the single reach from Zosel Dam downstream to the confluence with the Similkameen River. In this reach, flows are regulated by Zosel Dam and water flowing out of Osoyoos Lake remains clear under even high discharge conditions. Multiple-pass redd surveys of tributary habitats were conducted between April 16 and June 16. In Omak Creek, three surveys were conducted at established index areas, one extending 2 $\mathrm{km}$ upstream from the mouth of Omak Creek, the other between the lower-end of OBMEP Site 19 upstream to Mission Falls. Above Mission Falls, reaches were surveyed 
once during the post peak period using the downstream extent of the randomly selected EMAP sites upstream for $1 \mathrm{~km}$.

All steelhead redd surveys were conducted, and redds verified, by at least two Colville Tribal fisheries staff members trained in the application of the OBMEP redd survey methodology (Arterburn et al. 2007b). Main stem surveys were conducted by rafts. Tributary spawning areas were surveyed by foot. All island sections or other main stem areas that could not be floated due to limited access and/or obstacles (e.g. wood debris, braided channels, and diversions) were also surveyed by foot. Raft surveys were conducted by a minimum of two people using two, 1-man, 10' Skookum Steelheader model catarafts.

Redds were marked by GPS and surveyor flagging tied to bushes or trees on the streambank adjacent to the area where redds were observed. Individual flags were marked with the survey date, direction and distance from the redd/s, consecutive flag number, total number of redds represented by the flag, and surveyor initials. The same information was captured electronically by entering it into a Trimble GeoExplorer XT data logger. The color of the flagging was changed for each survey. Incomplete redds or test pits were not flagged and not counted. On subsequent surveys, all redds were counted and every attempt made to locate all flags from previous surveys. We noted missing flags by a gap in the numbering sequence. If a flag was found to be missing, the surveyor re-flagged redds based on the previously collected GPS location and information. Re-flagged redds were not counted as new redds.

GPS data and other information collected during field surveys were recorded on Trimble units and downloaded into GPS Pathfinder Office ${ }^{\circledR}$ after every survey. The GIS data were reviewed and spatially corrected to accurately display coordinates in a map format. Escapement calculations were made for each main stem reach, sub watershed and the entire Okanogan River population. We employed the method currently used by WDFW in the Upper Columbia Basin to extrapolate escapement estimates using the sex ratio of broodstock collected randomly over the run (Andrew Murdoch, WDFW, Pers. Comm.). For example, if the sex ratio of a random sample of the run is 1.5:1.0, the expansion factor for the run would be 2.5 fish/redd. This method is used for all supplemented stocks within the Upper Columbia Basin. We expanded this method by incorporating sex ratio data generated from the Omak Creek and Bonaparte Creek weirs in addition to using the sex ratio calculated from fish collected at Wells Dam. Both the total number of redds and spawning escapement were reported to the nearest whole number. 


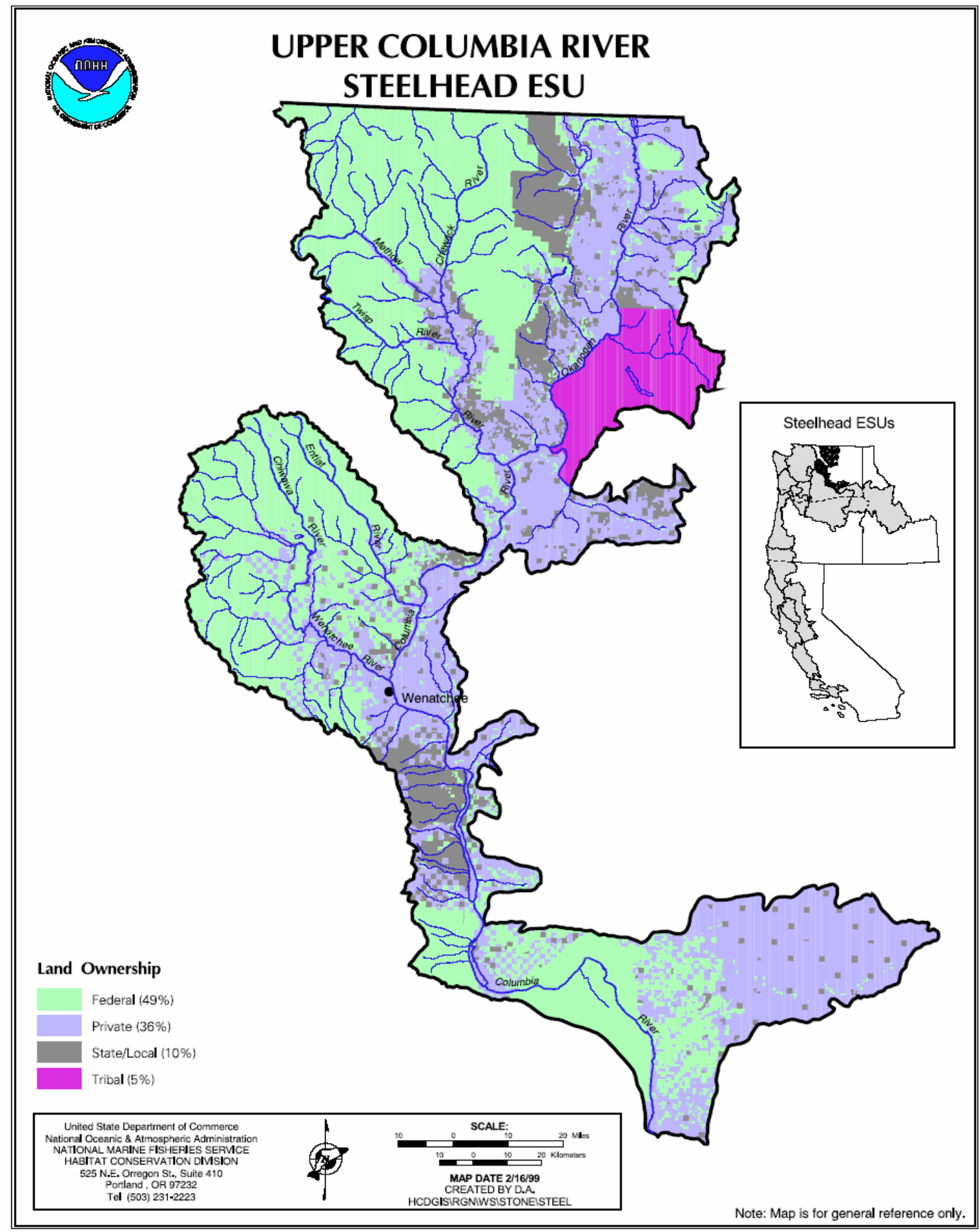

Figure 1: The Upper Columbia River summer steelhead Evolutionarily Significant Unit showing land ownership. Map courtesy of NMFS-HCD 
Table 1. Designated redd survey reaches with location description and reach length in kilometers used in the Okanogan Basin Monitoring and Evaluation Program.

\begin{tabular}{|c|c|c|}
\hline $\begin{array}{c}\text { Redd } \\
\text { Survey } \\
\text { Reaches }\end{array}$ & Location Description & $\begin{array}{l}\text { Reach } \\
\text { length }(\mathrm{km})\end{array}$ \\
\hline S1 & Similkameen/Okanogan Confluence(0) to Enloe Dam (14.6) & 14.6 \\
\hline 01 & $\begin{array}{l}\text { Okanogan River south of Chiliwist Creek(23.7) to Loup Loup } \\
\text { Creek(26.7) }\end{array}$ & 3.0 \\
\hline 02 & Okanogan River at Salmon Creek(41.4) to the Office(52.3) & 10.9 \\
\hline O3 & Okanogan River at the office(52.3) to Riverside(66.1) & 13.8 \\
\hline 04 & Okanogan River at Riverside(66.1) to Janis Bridge(84.6) & 18.5 \\
\hline 05 & Okanogan River at Janis Bridge(84.6) to Tonasket park(91.4) & 6.8 \\
\hline 06 & $\begin{array}{l}\text { Okanogan River at Horseshoe Lake(112.4) to Confluence with } \\
\text { Similkameen River(119.5) }\end{array}$ & 7.1 \\
\hline 07 & Okanogan River at confluence(119.5) to Zosel Dam(127.0) & 7.5 \\
\hline TU1 & $\begin{array}{l}\text { Tunk Creek @Okanogan River Confluence (0) to High water } \\
\text { mark }(0.2)\end{array}$ & 0.2 \\
\hline B1 & $\begin{array}{l}\text { Bonaparte Creek/Okanogan River confluence (0) to } \\
\text { Bonaparte Falls (1.6) }\end{array}$ & 1.6 \\
\hline N1 & $\begin{array}{l}\text { Ninemile Creek from Okanogan River confluence(0) to Eder } \\
\text { land (1.7) Maximum potential }(4.3 \mathrm{~km})\end{array}$ & 1.7 \\
\hline T01 & $\begin{array}{l}\text { Tonasket Creek/Okanogan River Confluence(0) to Tonasket } \\
\text { Falls (3.5) }\end{array}$ & 3.5 \\
\hline A1 & $\begin{array}{l}\text { Antoine Creek/Okanogan River Confluence(0) to Antoine } \\
\text { Barrier (1.3) }\end{array}$ & 1.3 \\
\hline L1 & $\begin{array}{l}\text { Loup Loup Creek/Okanogan River Confluence to Loup Loup } \\
\text { Falls (3.3) }\end{array}$ & 3.3 \\
\hline WS1 & $\begin{array}{l}\text { Wildhorse Spring Creek/Okanogan River Confluence to } \\
\text { Barrier (1.1) }\end{array}$ & 1.1 \\
\hline WC1 & $\begin{array}{l}\text { Whistler Cache Creek/Okanogan River Confluence to Barrier } \\
(0.7)\end{array}$ & 0.7 \\
\hline OM1 & $\begin{array}{l}\text { Omak Creek/Okanogan River Confluence(0) to Omak Lake } \\
\text { Rd. Bridge (2.0) }\end{array}$ & 2 \\
\hline OM2 & EMAP site 19 Lower (5.3) to Mission Falls (9.0) & 3.7 \\
\hline OM48 & EMAP site 48 Lower (25) to River Kilometer (26) & 1 \\
\hline OM393 & EMAP site 393 Lower 16.7) to River Kilometer (17.7) & 1 \\
\hline OM361 & Above Mission Falls (9.5) to EMAP site 345 (13.3) & 3.8 \\
\hline OM302 & River Kilometer (21.5) to EMAP site 302 lower (22.5) & 1 \\
\hline SC1 & Confluence with the Okanogan (0) to OID Diversion (7.2) & 7.2 \\
\hline
\end{tabular}




\section{Annual and Panel Map}

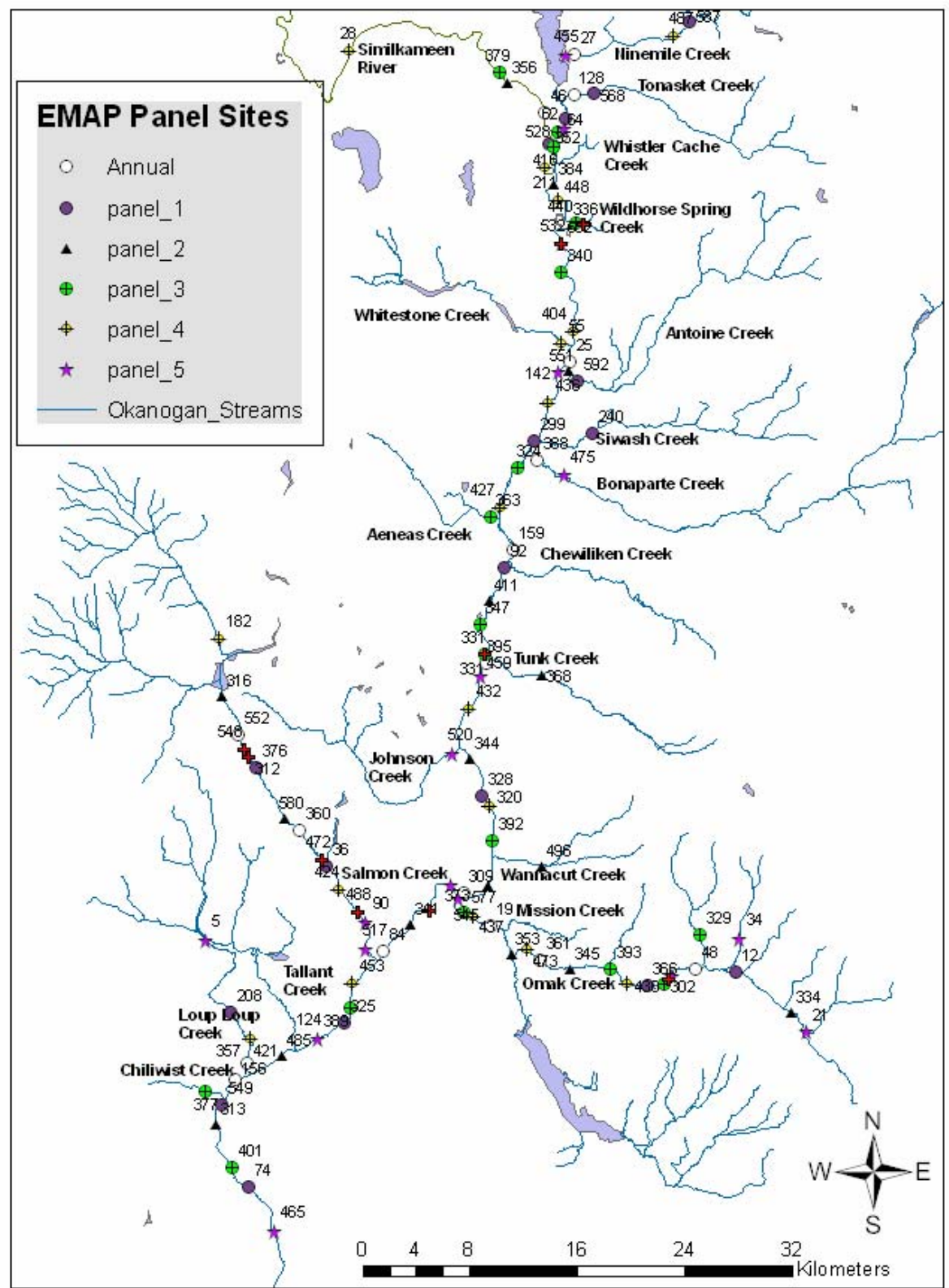

Figure 2: Probabilistic sampling design was used to select EMAP sites from a sampling universe that included all accessible habitats for anadromous fish in the United States portion of the Okanogan River Watershed. Annual sites are sampled annually and panel sites (1-5) are sampled once every 5 years on a rotating basis. 
Total redd estimates, in combination with spawner escapement where data exists (Omak Creek weir, Bonaparte Creek weir, and Zosel Dam counts), can be used to estimate total escapement with a high level of accuracy. Estimating redds in tributaries where landowner permission could not be granted represents a more difficult problem. The only way to expand estimates to the entire creek is to multiply the density of redds per $\mathrm{km}$ of stream in the sampled area by the remaining length of stream accessible by summer steelhead; this method was only needed for Ninemile and Salmon creeks.

Sex ratio data can be used to provide estimates of total spawner escapement for the reach, watershed or sub-watershed. The sex ratio was determined by counting and sexing all adult fish returning to Wells Dam, the Omak Creek and Bonaparte Creek weirs. The ratio of males to females is used for representative streams. Main stem habitats use Wells values, medium-sized tributaries use the sex ratio from the Omak Creek weir, and small streams use the sex ratio from the Bonaparte Creek weir, assuming that each female will produce one redd.

During the spring of 2007, high discharges did not allow us to survey the majority of main stem Okanogan River reaches. Therefore, we needed to estimate main stem redd numbers and distribution. In order to accomplish this we used two methods. First, we surveyed the reach from below Zosel Dam to the confluence of the Similkameen River (Reach O7). To estimate other reaches of the Okanogan River we determined the proportion of redds observed in this reach during the 2005 and 2006 redd surveys. This proportion was then applied to the other reaches along the Okanogan and Similkameen Rivers to estimate total main stem redd abundance. As a check-and-balance we also calculated escapement estimates using the WDFW Okanogan River escapement estimate (WDFW -unpublished data) which apportions summer steelhead to both the Methow and Okanogan rivers and accounts for all known recreational harvest. The WDFW

escapement estimate was used as a starting point to subtract known information related to tributary redd surveys, weir counts, and escapement into Canada. The number of redds was then calculated by estimating redds/reach based upon historic patterns of redd distribution.

\section{Results and Discussion}

Sex ratios

In 2007, 390 adult summer steelhead were sexed at Wells Dam, including 163-males and 227-females, for a sex ratio of 1.72 steelhead per redd (Charlie Snow, WDFW Pers. Comm.). At the Omak Creek trap, 97 adult summer steelhead consisting of 53-males and 44-females were collected. This makes a 1.2:1 male to female ratio and a number of fish per redd of 2.2 that will be applied to Omak Creek and other moderate-sized tributaries such as Salmon and Loup Loup creeks. On Bonaparte Creek, 164 summer steelhead were enumerated, of which 107 were male and 57 female, resulting in a sex ratio of 2.88. We assumed that other small tributaries had a similar sex ratio to Bonaparte Creek. 


\section{Percent wild}

Trap and dam counts provide the basis for determining the natal origin of summer steelhead in the Okanogan River basin. In 2007, WDFW estimated the number of wild summer steelhead that passed above Wells Dam at 552 or $8.27 \%$ of the total escapement. These values were based upon Wells Dam fish counts, scale analysis, hatchery releases, and stray rates estimated for Wells Hatchery (Charlie Snow, WDFW Pers. Comm.). The proportion of these fish assigned to the Okanogan River was 116 or $9.22 \%$ of the Okanogan River population. This percentage was applied to all main stem Okanogan reaches. We estimated the number and percent wild for summer steelhead that spawned in Omak Creek as 13 and 13.4\% of the total summer steelhead collected at the Omak Creek trap. Estimates for Bonaparte Creek were 21 or $12.8 \%$ of the steelhead collected at the Bonaparte Creek trap and was based upon the presence or absence of adipose fins and PIT-tags. At Zosel Dam, video images of the presence or absence of adipose fins were used to determine origin with 32 wild fish being counted, resulting in $21.77 \%$ of the run passing upriver of Zosel Dam being classified as natural origin. Three of these wild fish were apportioned to Tonasket and Ninemile creeks. The remaining 29 wild steelhead or 23.69\% were assumed to be destined for spawning habitat in Canada. The estimated total number of wild summer steelhead spawning in the Okanogan River subbasin was 152 or $12.01 \%$ of the total summer steelhead escapement in 2007.

\section{Okanogan River and Similkameen River Main Stem}

Discharge rates in 2007 in no way approximated normal, other than in the total amount of water that passed throughout the spring. Flows were five times the historic high flows during early April and remained higher than the historic mean until almost June (Figure 3). Extremely high flows prevented conducting redd surveys in the main stem Okanogan River below the confluence of the Similkameen River.

The Okanogan River was divided into seven segments for analysis. These segments were based on access points and included reaches on the Similkameen River. All reaches were located upstream of the Wells Pool influence that is commonly agreed to be at the confluence of Chiliwist Creek and the Okanogan River. Data collected in 2005 and 2006 were used as reference for main stem reach survey timing. In 2005, when flows on the main stem exceeded 3,000 cfs, visibility was too poor to continue with main stem redd surveys (Arterburn et al. 2005). Therefore, we had planned to begin main stem redd surveys April 1, 2007. However, due to extremely rare runoff conditions, discharge remained greater than 3,000 cfs and poor visibility conditions compromised our ability to conduct main stem surveys in reaches other than O7 (Figure 3). We estimated redds along the main stem Okanogan River in 2007 based on information we could collected in 2007 from reach O7 and past survey data from 2005 and 2006. Because elevated discharge compromised our ability to do most of our scheduled main stem redd surveys, we focused our efforts on expanded redd surveys in the tributaries. 
To estimate redds based upon one survey reach we first had to determine the historic proportion of redds for each of the main stem reaches. To do this we summed the number of redds counted from surveys conducted in 2005 and 2006 for each reach and divided this value by the total number of main stem redds observed to get a proportion of historic redds. We were able to complete redd surveys in reach O7 (150 redds) and the historic proportion of redds for this reach was estimated at $37.69 \%$. By dividing the number of redds observed in 2007 by the historic proportion we estimated the total number of redds we should have observed along all main stem reaches at 398 . This value was then multiplied by the historic proportion of the estimated reaches to compute the number of redds for each main stem reach. The estimated number of redds was multiplied by the sex-ratio from Wells Dam to estimate the number of spawners that these redds would represent. Because these estimates were based upon redd surveys on reach O7; to address inter-annual variability, our assumption was that the other reaches of the main stem would be equally impacted by visibility and runoff conditions. However, the clear water coming out of Zosel Dam made us question this a-priori assertion. The results from this effort are presented in Table 2 and compared to an alternative method used to QA/QC our results.

In the past, OBMEP redd surveys were used to estimate the number of spawners in the Okanogan River. Our spawner estimates have been compared to spawner escapement estimates developed by WDFW as part of our quality control efforts and our estimates have shown good correlation in both 2005 and 2006. Over concerns that our earlier method of estimating main stem redds would result in a biased estimate of spawners, we decided to calculate the number of redds from the WDFW spawner escapement estimate for comparison. This approach starts with the number of fish counted at Wells Dam $(6,674)$ from the DART web site http://www.cbr.washington.edu/dart/adult.html. Harvested fish are subtracted from this number and a split percentage is used to partition summer steelhead into the Methow River (79\%) and Okanogan River (21\%) values to estimate escapement (Bob Jateff, WDFW, Pers. Comm.). Using this method, the number of summer steelhead entering the Okanogan River was estimated at 1,258. Data from traps, video chambers, and tributary redd surveys were subtracted from 1,258 resulting in 418 adult spawners that were unaccounted. These unaccounted spawners plus the 258 spawners estimated from the redd surveys in reach $\mathrm{O} 7$ were distributed across the main stem reaches using the proportions that were developed by using our 2005 and 2006 redd surveys. The results from both methods were within three adult (395, 398, Table 2). Since the results were comparable we used the values from the a-priori approach to conduct the remaining analysis. 


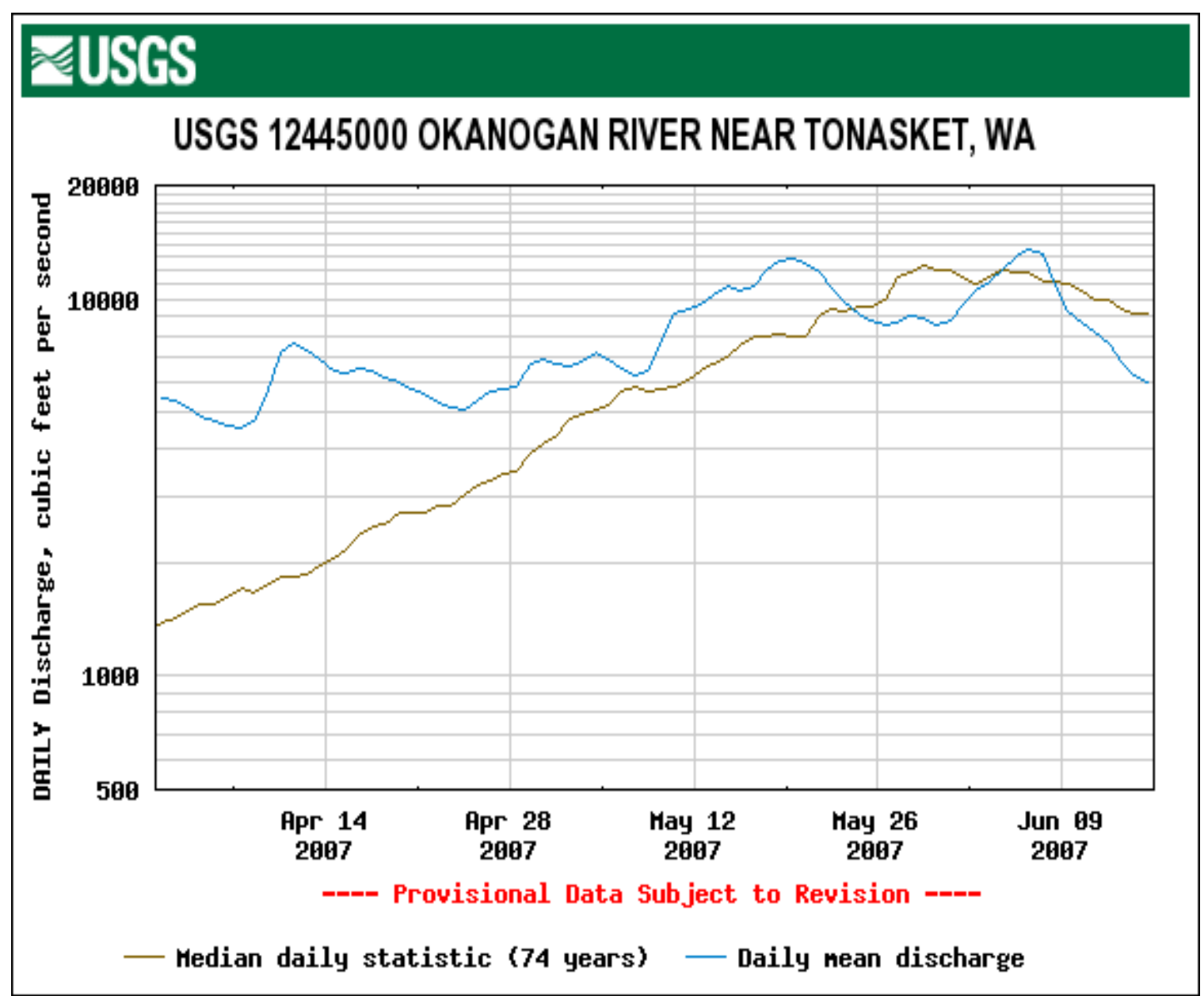

Figure 3: Okanogan River discharge for the period between April 1 and June 15, 2007. The 74-year historic average is also plotted on the graph for reference (http://waterdata.usgs.gov/wa/nwis/uv?12445000 ).

Okanogan River Reach O7 was surveyed three times in 2007 and a total of 150 summer steelhead redds were identified: April 3 (13 redds); April 17 (71 redds); and May 1 (66 redds). The majority of redds were observed between Zosel Dam and the Cross Channel in 2007, which is similar to results in 2006 (Figure 4). During peak spawning, numerous summer steelhead were observed constructing or near redds. We estimated that the number of summer steelhead spawning in this reach was 258 and 24 were of natural origin. We calculated a redd density of 34.4 redds per $\mathrm{km}$ in this reach.

The timing of summer steelhead redd construction in 2005 progressed from the lower river northward with peak activity around the middle of April in the main stem reaches. In 2006, redd construction timing did not follow a specific pattern and varied by location from early to late April. In 2007, redd construction timing in Reach O7 was very similar to 2006 with most redds created in early- to mid-April and fewer redds observed during the late April survey. Reach O7 did continue to attract many spawning adult summer steelhead, particularly between Zosel Dam and the Cross Channel above Driscoll Island. Where habitats were conducive, steelhead built redds in close proximity to one another, especially in pool tail-out areas and at the heads of mid-channel islands. 
Table 2: Comparison of number of redds estimated using two different methodologies. The 2007 Reach 07 estimate applied the historic proportions of redds observed to the data collected in 2007 in the O7 reach. The Wells Dam estimated redd count begins with the WDFW predicted adult spawner escapement and subtracts all known adult spawner estimates from redd surveys, trap data, and video data collected in 2007. The remaining fish were then apportioned amongst the main stem reaches based upon historic distributions, then divided by the sex ratio for Wells Dam in order to estimate the number of redds in each reach. The number of redds observed during steelhead redd surveys in 2005 and 2006, with reference reach length, description, and designation for these observations are also presented. Values coded by * are estimated values

\begin{tabular}{|c|c|c|c|c|c|c|}
\hline $\begin{array}{c}\text { Reference } \\
\text { Reaches }\end{array}$ & Description (river-KM) & $\begin{array}{c}\text { Reach } \\
\text { length } \\
\text { (KM) }\end{array}$ & $\begin{array}{l}2005 \\
\text { (redd } \\
\text { count) }\end{array}$ & $\begin{array}{l}2006 \\
\text { (redd } \\
\text { count) }\end{array}$ & $\begin{array}{c}2007 \text { Reach } 07 \\
\text { (*Estimated redd } \\
\text { count) }\end{array}$ & $\begin{array}{c}2007 \text { Wells Dam } \\
\text { (*Estimated redd } \\
\text { count) }\end{array}$ \\
\hline $\mathrm{O} 1$ & $\begin{array}{c}\text { Okanogan River south of } \\
\text { Chiliwist Creek(23.7) to } \\
\text { Salmon Creek(41.4) }\end{array}$ & 28.5 & 17 & 0 & 9* & $9 *$ \\
\hline $\mathrm{O} 2$ & $\begin{array}{l}\text { Okanogan River @ } \\
\text { Salmon Creek(41.4) to } \\
\text { CCT Office }(52.3)\end{array}$ & 10.9 & 56 & 4 & $31^{*}$ & $30^{*}$ \\
\hline $\mathrm{O} 3$ & $\begin{array}{c}\text { Okanogan River @ CCT } \\
\text { Office(52.3) to } \\
\text { Riverside(66.1) }\end{array}$ & 13.8 & 8 & 2 & $5^{\star}$ & $5^{*}$ \\
\hline $\mathrm{O} 4$ & $\begin{array}{c}\text { Okanogan River @ } \\
\text { Riverside(66.1) to Janis } \\
\text { Bridge(84.6) } \\
\end{array}$ & 18.5 & 58 & 11 & $35^{*}$ & $35^{*}$ \\
\hline O5 & $\begin{array}{l}\text { Okanogan River @ Janis } \\
\text { Bridge(84.6) to Mouth of } \\
\text { Siwash Creek(93.8) }\end{array}$ & 14.8 & 65 & 39 & $53^{*}$ & $52^{*}$ \\
\hline $\mathrm{O} 6$ & $\begin{array}{l}\text { Okanogan River @ Mouth } \\
\text { of Siwash Creek(93.8) to } \\
\text { Confluence of the } \\
\text { Similkameen River(119.5) }\end{array}$ & 41.4 & 19 & 1 & $10^{*}$ & $10^{*}$ \\
\hline $\mathrm{O} 7$ & $\begin{array}{l}\text { Okanogan River at } \\
\text { Confluence of the } \\
\text { Similkameen(119.5) to } \\
\text { Zosel Dam(127.0) }\end{array}$ & 7.5 & 141 & 153 & 150 & 150 \\
\hline S1 & $\begin{array}{c}\text { Similkameen River @ } \\
\text { Okanogan confluence(0) to } \\
\text { Enloe Dam (14.6) }\end{array}$ & 23.5 & 106 & 100 & $105^{*}$ & $104^{*}$ \\
\hline Total & Okanogan River & & 470 & 310 & 398 & 395 \\
\hline
\end{tabular}




\section{Redd Survey Reach 07-2007}

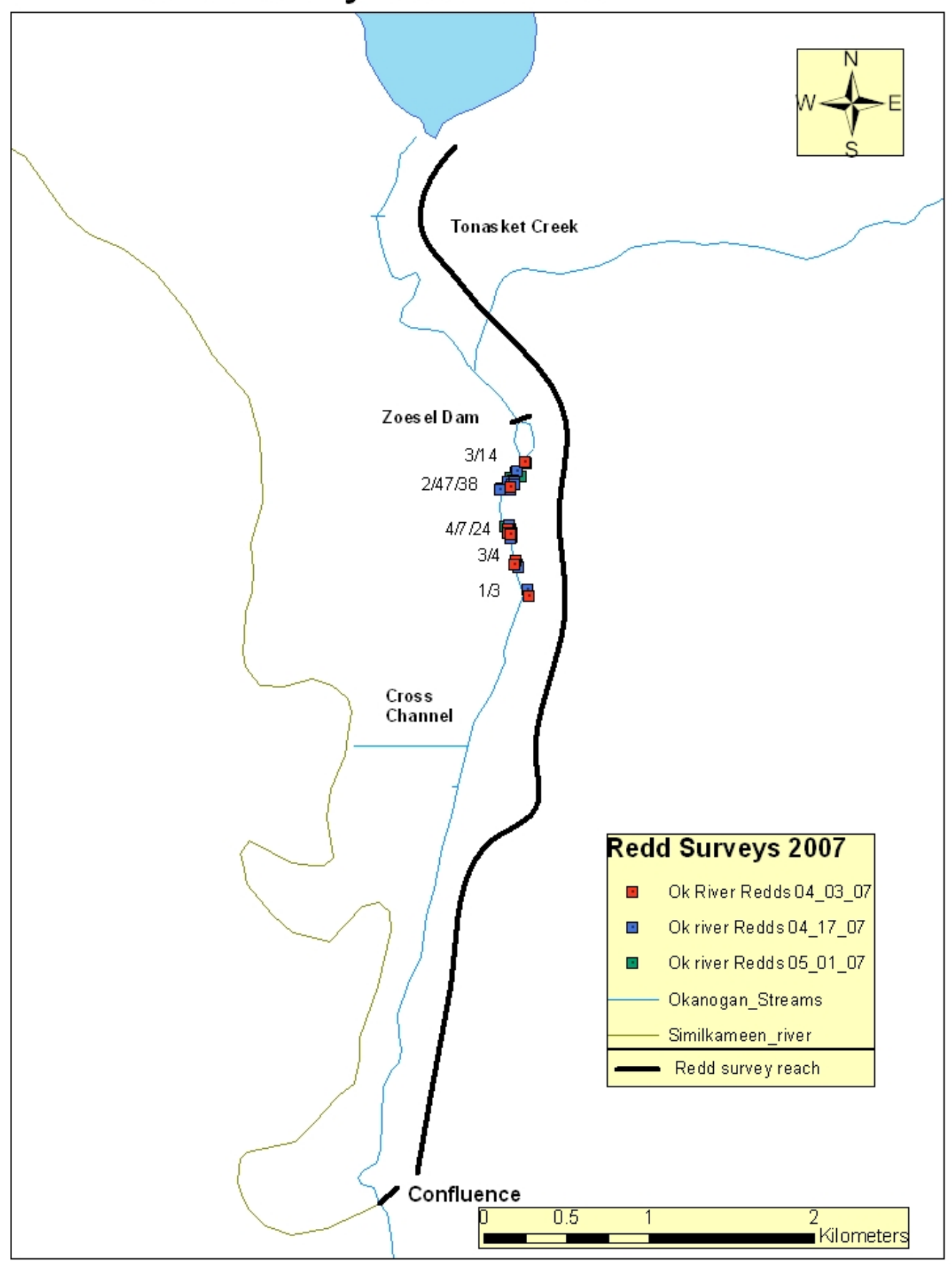

Figure 4: Redd distribution observed in 2007 for Okanogan River Reach O7 from Zosel Dam downstream to the confluence with the Similkameen River. 
Tributary redd surveys in the Okanogan River basin

Tributary habitats were originally planned for survey during the first week of June. However, high water in the Okanogan River provided an opportunity to conduct multiple-pass redd surveys over an extended area beginning April 16 with final surveys completed on June 11, 2007. Tributary runoff during 2007 was moderated by cool, dry weather throughout the period that allowed the slightly above average snowpack to melt in an orderly manner. This provided excellent conditions for multiple redd surveys in most tributaries throughout the survey timeframe.

In 2007, most tributary streams reached peak discharge by mid-March and steadily decreased throughout the spawning period. A normal hydrograph consists of an ascending limb in March and April then peaking in mid- to late-May. The almost complete lack of spring precipitation resulted locally in a very controlled runoff in the tributary streams (Table 3). Elevated discharge in the Okanogan River provided unimpeded access into most tributaries, as indicated by 156 steelhead entering Bonaparte Creek. However, minimal precipitation resulted in diminished discharges from most tributaries and limited spawner distribution (Figure 5).

Table 3: Precipitation totals measured by the National Weather Service at Omak Airport http://www.crh.noaa.gov/product.php?site=NWS\&issuedby=OMK\&product=CLM\&format=CI\&version= 6\&glossary $=0$

\begin{tabular}{|c|c|c|c|}
\hline Month & $\begin{array}{c}\text { Inches of } \\
\text { precipitation in 2007 }\end{array}$ & $\begin{array}{c}\text { Inches of } \\
\text { precipitation in 2006 }\end{array}$ & $\begin{array}{c}\text { Inches of precipitation on } \\
\text { Average }\end{array}$ \\
\hline March & 0.08 & 0.81 & 1.00 \\
\hline April & 0.06 & 0.89 & 1.00 \\
\hline May & 0.74 & 1.35 & 1.08 \\
\hline Total & 0.88 & 3.05 & 3.08 \\
\hline
\end{tabular}

Each tributary of the Okanogan River represents a unique data set; therefore the results of each tributary are described individually.

\section{Ninemile Creek}

Lack of access to private lands has been an ongoing problem on Ninemile Creek. No exhaustive survey of fish passage barriers has been possible due to an uncooperative landowner. However, the Colville Tribes Fish and Wildlife Department's personnel have incrementally documented migration barriers within this watershed (Arterburn et al. 2007). We have verified that anadromous fish have access to a minimum of $1.7 \mathrm{~km}$ (lower extent of private lands) and a maximum of $4.3 \mathrm{~km}$ (impassable falls) of spawning and rearing habitat. Surveys uncovered one impediment at river kilometer 1.3 and this blockage could be a complete barrier during low water years such as 2005 and 2007 (Figure 5). Extrapolating redd surveys is limited to the maximum habitat available but this evaluation is subject to change as additional habitat information is gained. Within the lower $1.7 \mathrm{~km}$, two redds were identified on April 18, 2007 and one on May 2, 2007 (Figure 6). No redds or summer steelhead were observed during the final survey on 
May 16, 2007. Escapement was estimated between 9 and 22 summer steelhead with a density of 1.76 redds $/ \mathrm{km}$. However, it is suspected that our lower estimate is more representative due to lack of sufficient flows which likely limited access. If we assume escapement into Ninemile Creek was 9 summer steelhead then one of these fish was likely of natural origin.

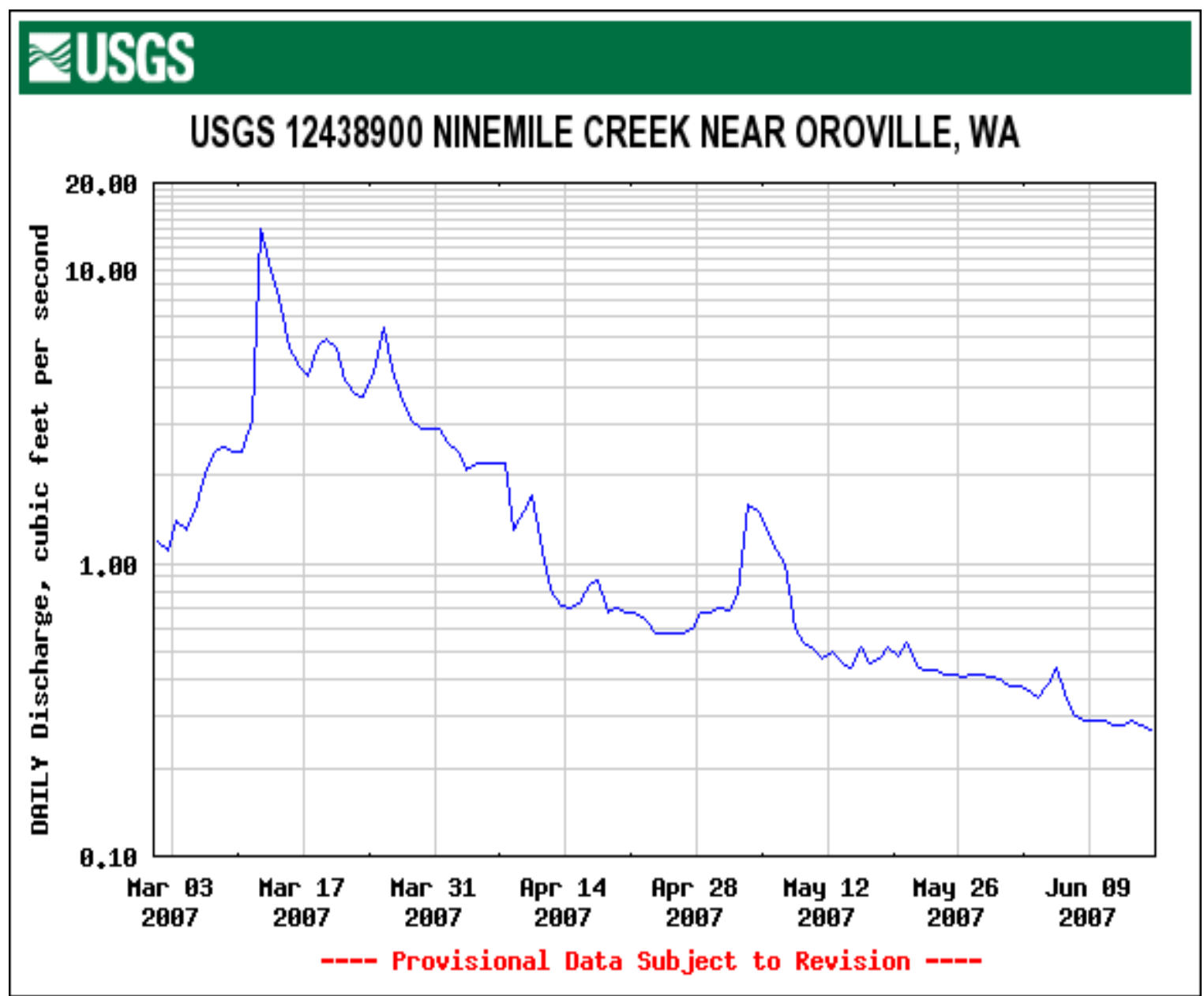

Figure 5: Discharge graph for Ninemile Creek. Flows below 1.0 cfs make it extremely difficult for adult steelhead to migrate through or spawn in this stream.

\section{Tonasket Creek}

Tonasket Creek had good flows throughout the steelhead spawning season in 2007. The barrier to upstream migration is a natural falls at river km 3.5 (Arterburn et al. 2007). Only during the second survey were redds observed. Six redds were observed on April 27, 2007 (Figure 6). The escapement for Tonasket Creek was estimated at 17 summer steelhead with a density of 4.86 redds $/ \mathrm{km}$. From these estimates, we predict that 2 wild steelhead returned to Tonasket Creek in 2007. 


\section{Ninemile(N1)and Tonasket Creek(T1) Redds 2007}

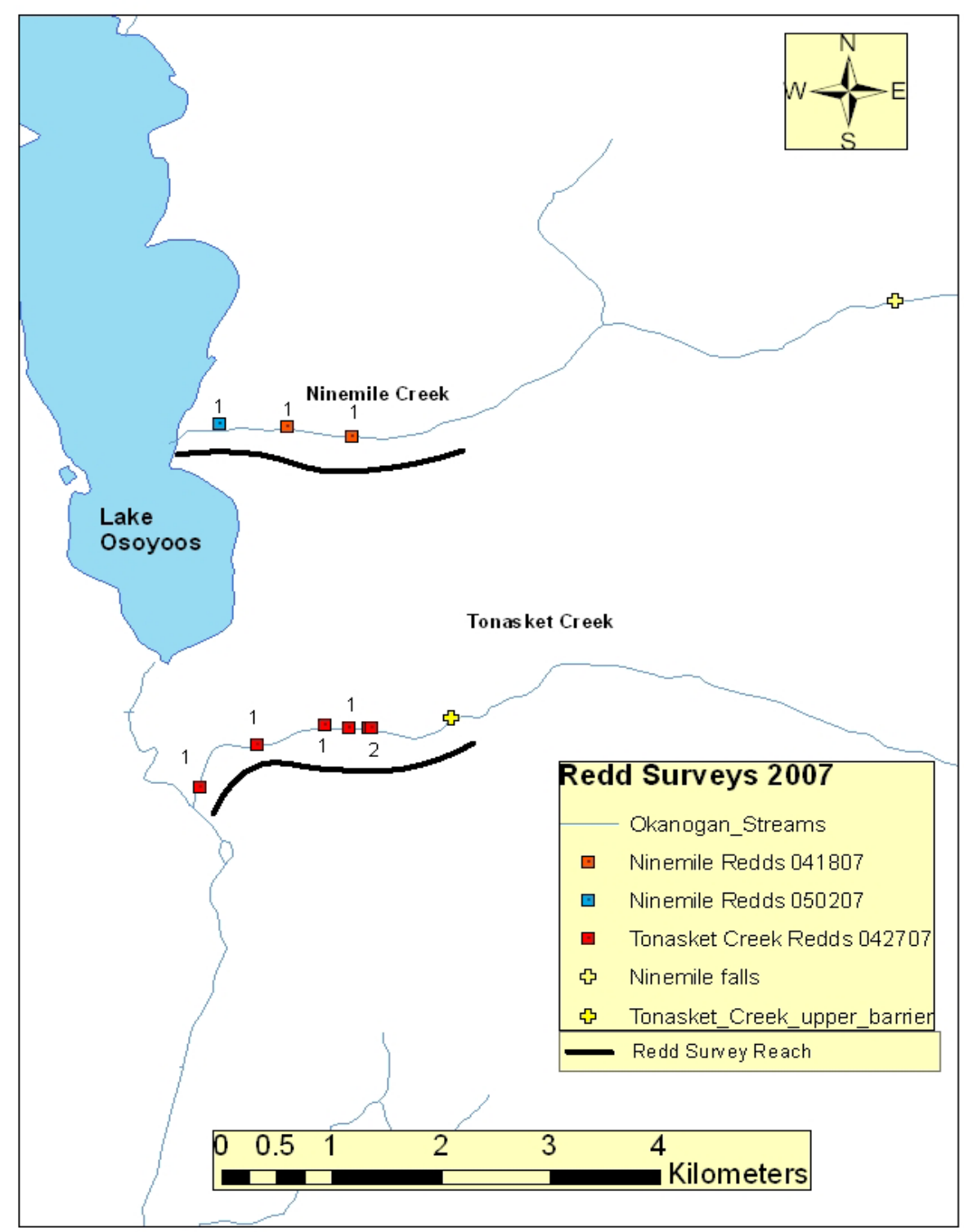

Figure 6: Redd distribution observed in 2007 for Ninemile and Tonasket Creek in the accessible lower portions of each creek.

\section{Wildhorse Spring Creek}

Wildhorse Spring Creek had been inaccessible prior to 2006 due to a large beaver dam located near the confluence with the Okanogan River. However, high flows in 2006 dislodged this dam. With the barrier removed summer steelhead began colonizing these habitats. In 2006 three redds were observed by OBMEP crews and verified by WDFW biologists. Again in 2007, steelhead redds were observed within the $1.1 \mathrm{~km}$ of available habitat. One adult steelhead was observed on April 8, 2007, and no redds or fish were observed on April 23, 2007. Seven redds were observed during a survey conducted on May 24, 2007 (Figure 7). Some uncertainty does exist regarding these redds as the 
substrate size was smaller than usual for summer steelhead and the size of observed redds were also smaller than one would typically equate with summer steelhead for all redds observed. At adult traps on Omak and Bonaparte creeks, several small steelhead were captured during 2007. Also, the close proximity of redds suggests that more than one redd may have been constructed by one fish, or may have been "test pits". Using our apriori methodology we would estimate these redds to represent 20 spawning adults at a density of 6.4 redds $/ \mathrm{km}$. However, due to some uncertainty related to these redds, a minimum estimate would be 12 adults using the using the Wells Dam sex ratio. Naturalorigin steelhead predictions would range between 2 and 3 fish. Based upon channel dimensions, size of substrate, and no adult steelhead observed during surveys, the lower number of adults is likely more accurate. .

\section{Whistler Cache Creek}

During 2007, field crews attempted to do three redd surveys but the creek was dry so no redds were observed. After doing redd surveys in 2006 during which water was present in this stream and attempting them again in 2007. We believe that this stream does not have any spawning potential for summer steelhead (Figure 7). Therefore, no further spawning surveys are planned along this creek.

\section{Antoine Creek}

Antoine Creek typically has perennial discharge but had limited discharge for adult passage throughout the 2007 steelhead spawning season. Although we surveyed the stream on April 11, April 24, and May 14, we did not observe any summer steelhead adults nor redds. The barrier to upstream migration has been located at river kilometer 1.3 where a bedrock feature and irrigation diversion exists (Arterburn et al. 2007). Therefore, escapement was zero in 2007. Snorkel surveys have identified multiple yearclasses of both brook and rainbow trout indicating that some rearing habitat does exist (Kistler et al. 2006, Kistler and Arterburn 2007). However, in most years the mouth of this tributary is difficult for adult fish to navigate. Redd surveys conducted during 2007 indicate the need for modifying the confluence area to ensure access during typical flow conditions. In addition, hatchery supplementation of locally-adapted hatchery steelhead smolts would "seed" the available habitat in this creek resulting in an increased likelihood that adults would return to this stream to spawn. 


\section{Wildhorse Spring Creek Redds 2007}

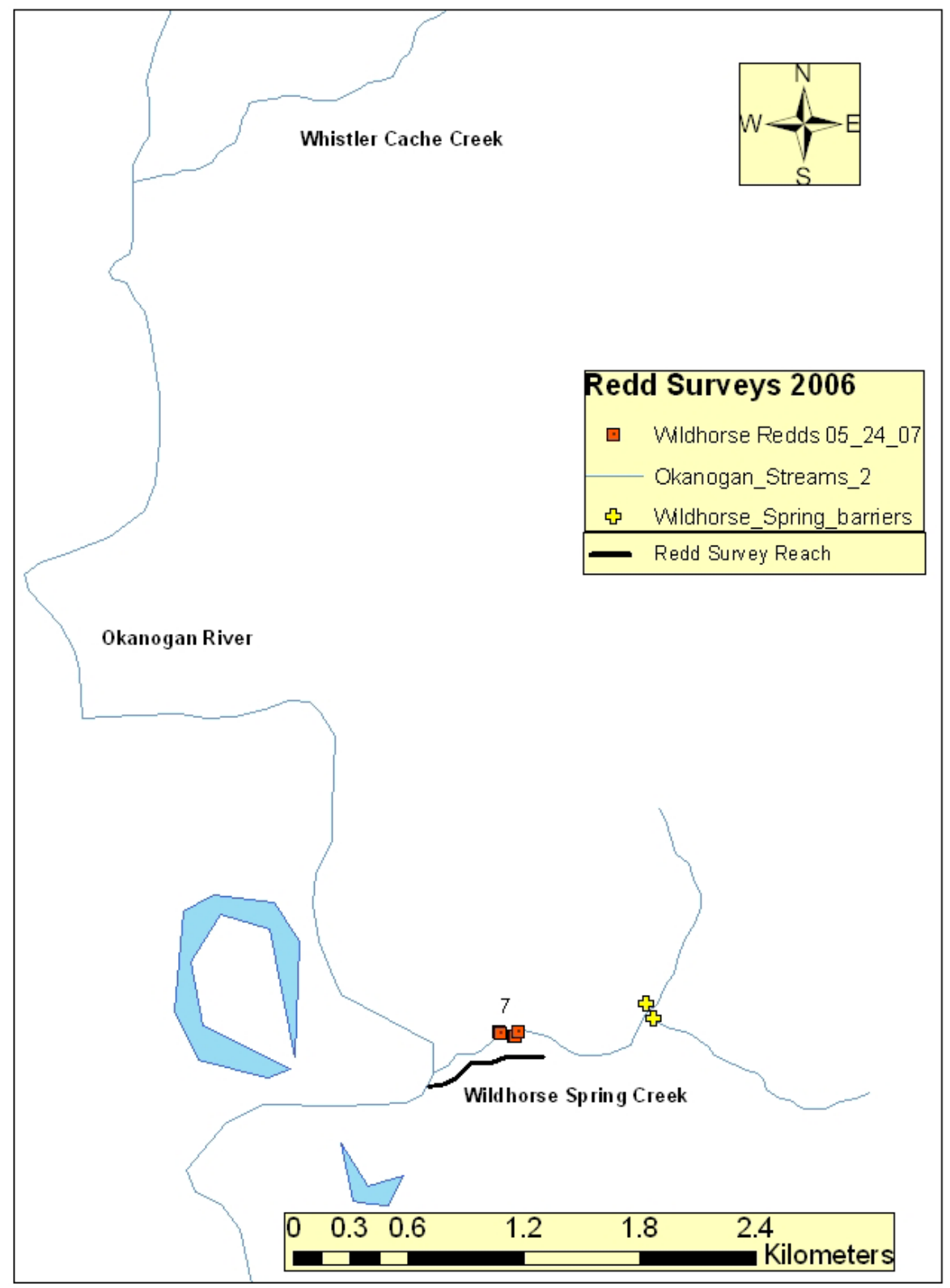

Figure 7: The location of redds within the Whistler Cache Creek and Wildhorse Spring Creek sub-watersheds in 2007.

\section{Bonaparte Creek}

In 2007, a picket weir trap was installed on March 28. We captured 164 summer steelhead, including 57 females, and 107 males and 21 being of natural origin. Since this trap was considered impassable, redd surveys to generate spawner estimates were not necessary above the trap. Furthermore redd surveys during 2005, and 2006 exhibited an even distribution throughout the 2.2 kilometers of accessible habitat (Arterburn et al. 
2005, Arterburn and Kistler 2006, Arterburn et al. 2007). Redd surveys downstream of the weir were not conducted until July 31 due to elevated water height on the Okanogan River which precluded streambed observations. Although obscure, 13 summer steelhead redds were identified below the trap site (Figure 8). Based upon the sex ratio generated from the trap data, an estimated 37 summer steelhead spawned downstream of the trap site. Of the fish enumerated at the trap, $12.8 \%$ were of natural origin. An additional 5 fish of natural-origin spawned downstream of the trap site. Redd density was calculated at $32.27 / \mathrm{km}$ which is the highest density since 2005 when a density of $41.88 / \mathrm{km}$ was observed (Arterburn et al. 2005). The total number of spawners was 204, of which 26 were of natural origin. Due to the abundance of adult steelhead returning to Bonaparte Creek, and the limited spawning and rearing habitat, Bonaparte Creek should be seriously considered as a future site for locally adapted broodstock collection.

\section{Tunk Creek}

Adult summer steelhead may have entered the lower portion of Tunk Creek and spawned successfully. However, as access is not permitted by the landowner from the confluence upstream to the base of Tunk Falls, our redd surveys have always been limited to the area within the high-water mark of the Okanogan River. In 2007, high water along the Okanogan River made it impossible to survey for redds even within the lowest reach of Tunk Creek as has occurred in past years. Previous redd surveys identified 4 redds in 2005 and 1 redd in 2006 within the lower $0.2 \mathrm{~km}$ of Tunk Creek. These observations were extrapolated into adult escapement estimates of 7 to 46 summer steelhead in 2005 and 2 to 7 summer steelhead in 2006 (Arterburn et al., 2005; Arterburn and Kistler 2006). Because only a very limited area of Tunk Creek is accessible for redd surveys it is hard to hypothesize about cause and effect relationships. Because we have only minimal data for Tunk Creek, our 2007 escapement estimate must remain unknown.

\section{Wanacut Creek}

Although this creek has a sizeable watershed (roughly 22,000 acres), data is scarce primarily due to discontinuous surface flow within the lower 1 kilometer. During 2006, a falls was documented at river kilometer 2.64 defining the extent of accessible habitat by anadromous salmonids (Arterburn et al. 2007). During the spring of 2007, Swimptkin Canyon, Pothole Canyon, and Wanacut creeks were all flowing and accessible by summer steelhead. All three creeks were surveyed on April 12 and April 19, 2007, but no redds were observed. However by April 25, both Swimptkin and Pothole Canyon creeks had stopped flowing. Wanacut Creek was still flowing; one redd and one adult summer steelhead were observed (Figure 9). A final survey was conducted on Wanacut Creek on May 15, 2007, and documented no additional redds or adult fish. Redd densities were estimated at 0.38 redds $/ \mathrm{km}$ and we estimated that 3 adult summer steelhead spawned in Wanacut Creek but none were of natural origin. This stream should be considered for supplemental stocking from a locally-adapted hatchery program to encourage greater adult returns. 


\section{Bonaparte Creek Redds-2007}

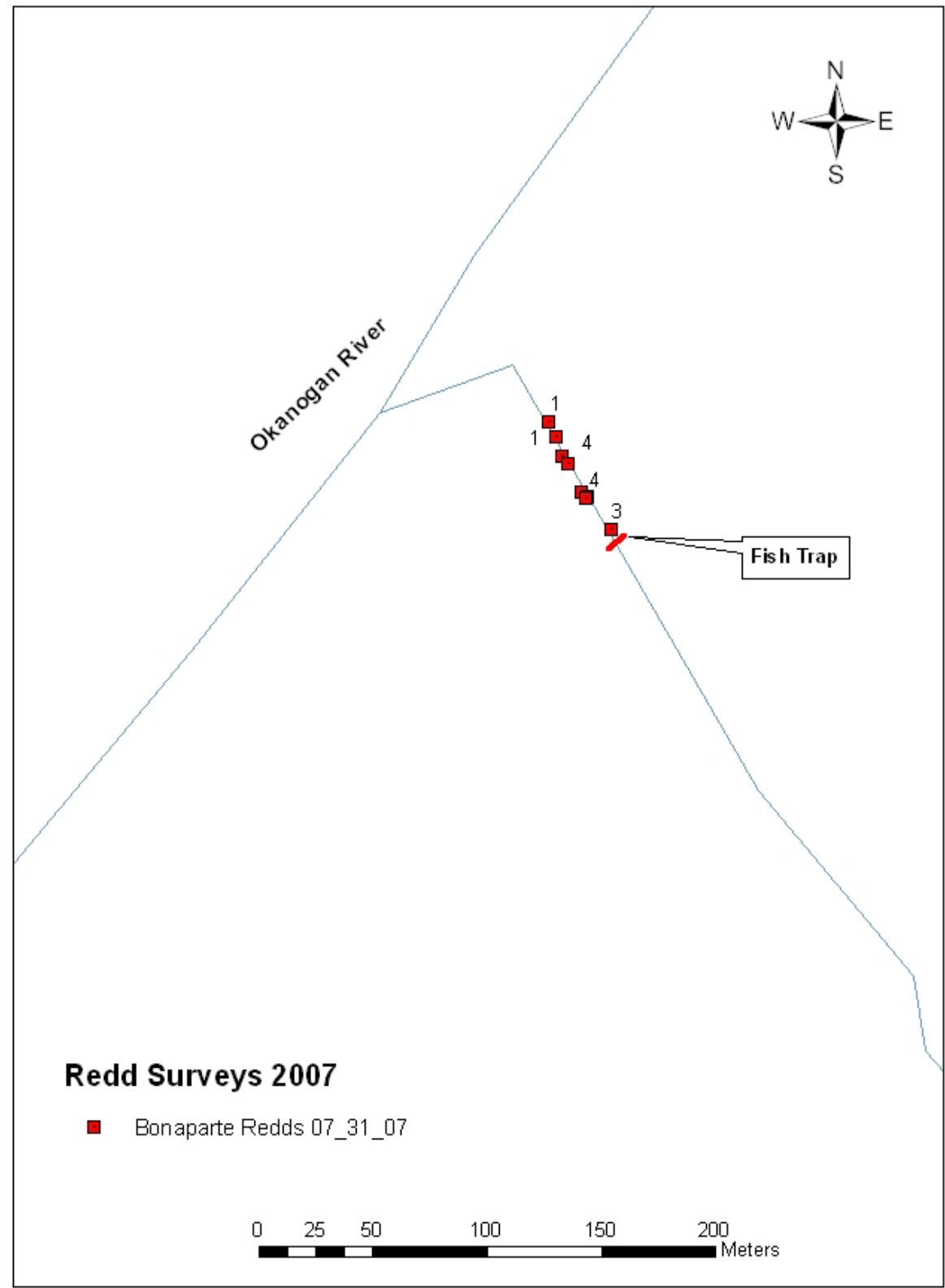

Figure 8: Steelhead redd distribution in Bonaparte Creek during 2007 from the confluence with the Okanogan River upstream to the picket weir trap. 


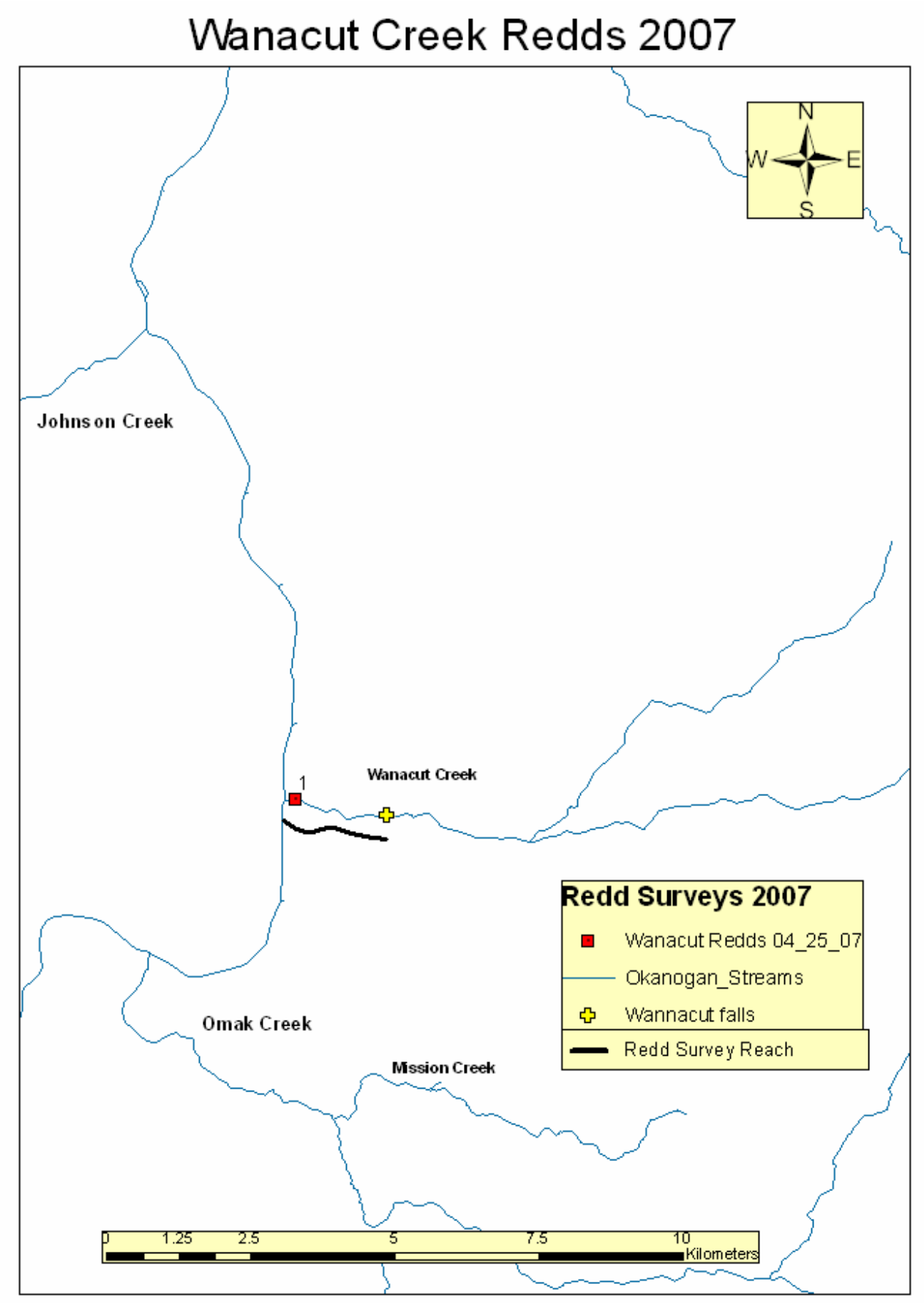

Figure 9: Steelhead redd distribution in Wanacut Creek during 2007 from the confluence with the Okanogan River upstream to the falls. 


\section{Omak Creek}

At the trap on Omak Creek, 10 adult spring Chinook salmon and 97 adult summer steelhead were captured during 2007. The summer steelhead trapped included 53 males and 44 females, including 13 of natural origin. A total of 25 redds were observed downstream of the trap during our survey on June 1, 2007 (Figure 10).

Nine kilometers of spawning habitat are accessible in Omak Creek below Mission Falls and an additional 22 kilometers are available upstream. However, Mission Falls is considered a significant impediment to fish passage. Three redd surveys were conducted in the lower $9 \mathrm{~km}$ on April 16, April 30 and June 1, 2007. A total of 24 redds were identified including 2 within the lowermost reach below Mission Falls (Figure 10). Upstream of Mission Falls, redd surveys were conducted on May 30 (lowermost reach of Stapaloop Creek) and June 13 when reaches OM48 and OM334 were surveyed. No redds were identified during surveys above Mission Falls.

Based upon the number of redds downstream of the trap and the number of fish captured at the Omak Creek weir, we estimated that 153 adult summer steelhead, of which 20 were of natural origin, spawned in Omak Creek during the spring of 2007. The density of redds downstream of Mission Falls was estimated at 7.73 redds $/ \mathrm{km}$, which is the highest density since 2005. Recent efforts to provide fish passage at Mission Falls do not appear to have expanded the spawning distribution. However, redds have been observed within the falls near recently installed passage structures. Due to the previous investments and the amount of potential habitat available upstream of Mission Falls, investigations to augment passage should continue. As efforts to address passage at Mission Falls continue, so should redd surveys as a means of evaluating the effectiveness of improvement efforts.

\section{Salmon Creek}

Historically, Salmon Creek has been diverted for irrigation purposes. The resulting dry stream channel extends from the OID diversion dam located at river kilometer 7.2 to the confluence with the Okanogan River. Occasionally, uncontrolled spills have occurred downstream of the OID's diversion dam. These releases, usually occurred after summer steelhead spawning (mid-May to June), and resulted in a torrent of water being released that is conducive for neither adult passage nor spawning However, summer steelhead passage flows were evaluated during a controlled release of $25 \mathrm{cfs}$ from April 1 through April 14, 2003. During this 2 week period, 6 redds were constructed within the lower reach of Salmon Creek (Fisher and Arterburn 2003).

As a result of these passage evaluation studies, a long-term water lease was negotiated between the Colville Tribes and the Okanogan Irrigation District (OID) which provided sufficient water for a smolt release in 2007. In the future, this agreement will provide water sufficient for both the adult and smolt steelhead to migrate through the lower $7.2 \mathrm{~km}$ of Salmon Creek once the channel configuration is modified. The OID controlled 
releases began on April 29, 2007 according to an agreed upon varied release schedule (Table 4).

\section{Omak Creek Redd Surveys 2007}

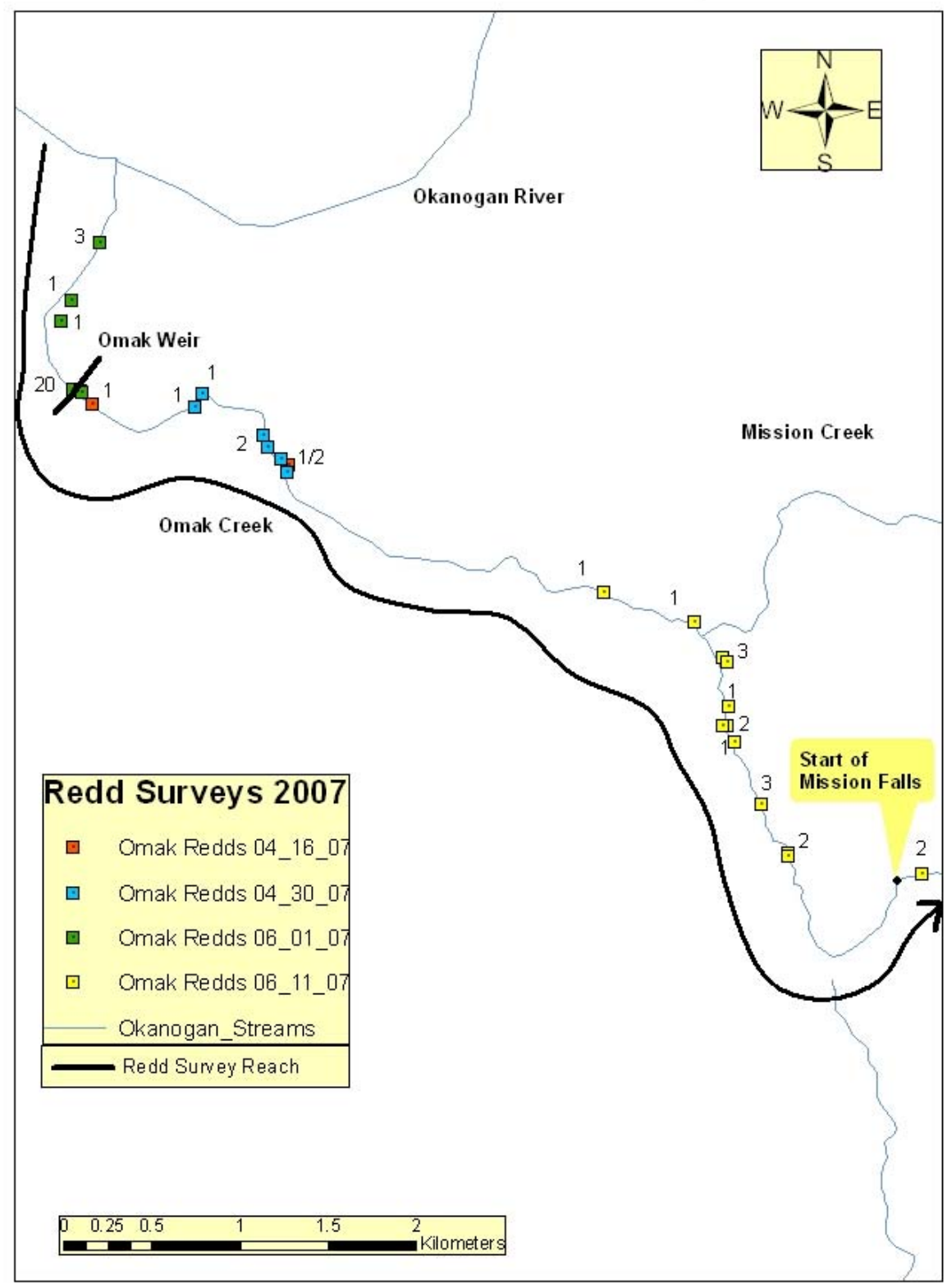

Figure 10: Omak Creek steelhead redd distribution downstream of Mission Falls in 2007.

A redd survey was conducted on June 4, 2007, shortly after flows were reduced downstream of the OID diversion. Redd surveys upstream of this point were limited due to lack of landowner permission. The fishway at the OID diversion would provide an excellent location to enumerate adult fish using a removable video counting station or trap. Six redds were identified during this survey downstream of the OID diversion 
(Figure 11). However, it is unknown how many fish, if any, migrated above this point. A minimum number of spawners from these redds is estimated at 13 of which two would have been of natural origin. These redds result in a redd density of $0.63 / \mathrm{km}$. Expanding the observed redds to include all habitat downstream of Conconully Dam results in an estimated 21 redds, or 46 summer steelhead, of which 6 would be of natural origin. Because there are no known passage impediments, the estimate for all available habitats is likely more representative of the number of adults that utilized Salmon Creek during 2007.

Enumeration of spawners using Salmon Creek would be much improved with the addition of a video counting station or removable trap, custom-designed to fit the fish ladder at the OID diversion. Dramatic increases in steelhead production are anticipated due to the water lease agreement signed between the Colville Tribes and OID. By synchronizing water releases to coincide with adult steelhead migration timing, more redds will be constructed near areas with excellent rearing habitat.

Table 4. Varied water release schedule for the OID diversion dam on Salmon Creek. (Start/end date and exact discharge may vary, depending upon survey of channel and success of smolt out migration). Conversion: 1.98 acre-foot $=1 \mathrm{cfs}$ for 24 hours.

\begin{tabular}{|l|c|c|}
\hline DATE & Flow (cfs) & Volume (acre-feet) \\
\hline April 29 & 5 & 9.9 \\
\hline April 30 & 5 & 9.9 \\
May 1 & 5 & 9.9 \\
\hline May 2 & 10 & 19.8 \\
\hline May 3 & 10 & 19.8 \\
\hline May 4 & 10 & 19.8 \\
\hline May 5 & 10 & 19.8 \\
May 6 & 20 & 39.6 \\
May 7 & 20 & 39.6 \\
May 8 & 30 & 59.4 \\
\hline May 9 & 30 & 59.4 \\
May 10 & 20 & 39.6 \\
May 11 & 20 & 39.6 \\
May 12 & 10 & 19.8 \\
May 13 & 10 & 19.8 \\
\hline May 14 & 30 & 59.4 \\
May 15 & 30 & 59.4 \\
May 16 & 30 & 59.4 \\
May 17 & 20 & 39.6 \\
May 18 & 10 & 19.8 \\
May 19 & 10 & 19.8 \\
May 20 & 5 & 9.9 \\
May 21 & 5 & 9.9 \\
May 22 & 5 & 9.9 \\
TOTAL & & $\mathbf{7 1 2 . 8}$ \\
\hline
\end{tabular}




\section{Salmon Creek Redds 2007}

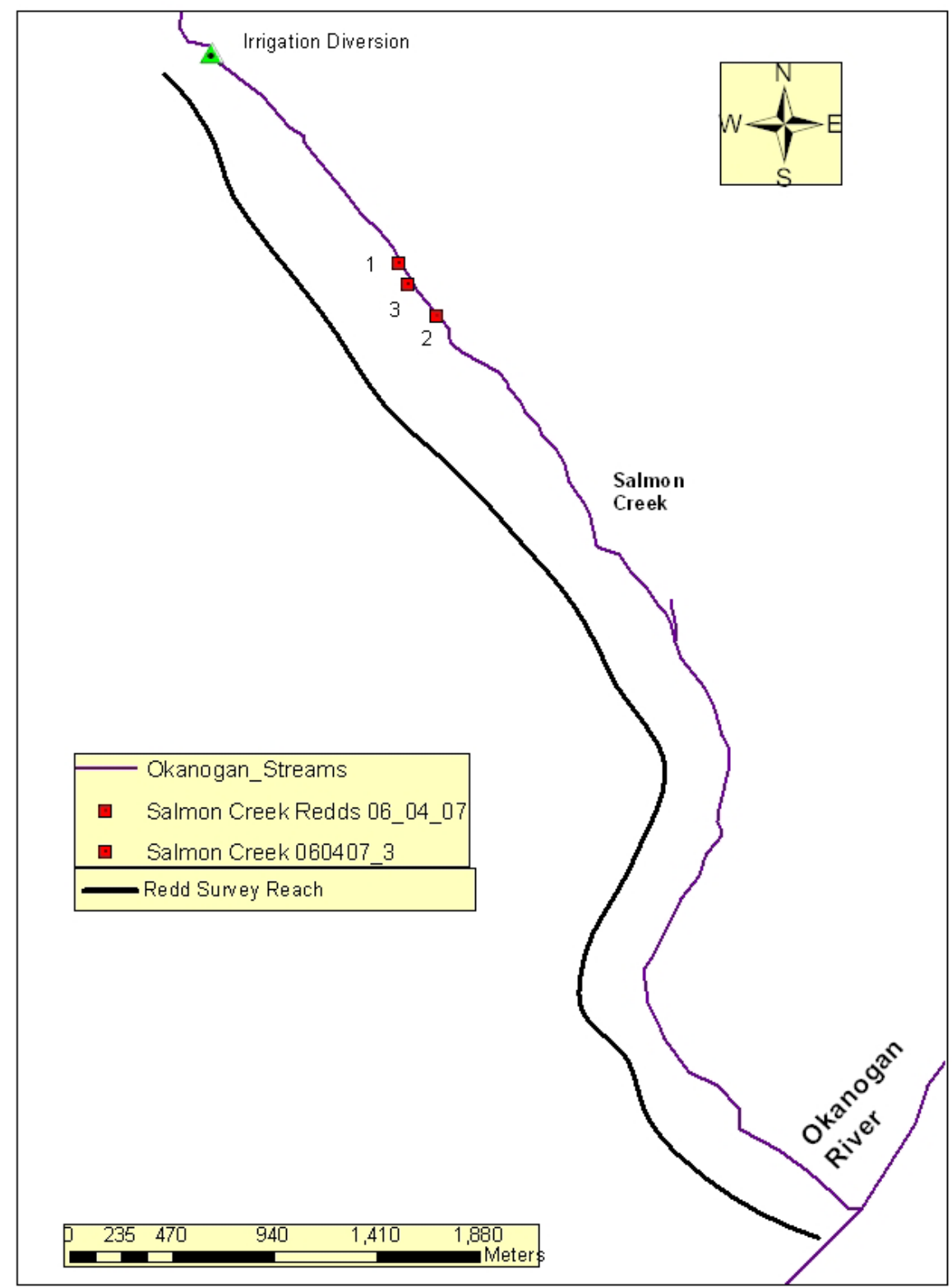

Figure 11: Steelhead redd distribution in Salmon Creek downstream of the Okanogan Irrigation District's diversion dam during 2007. 


\section{Loup Loup Creek}

Loup Loup Creek was initially surveyed for redds on April 6, 2007, but no redds were observed. A second survey was conducted on April 20. During the second survey, one adult steelhead and three redds were identified. The Helensdale irrigation diversion was closed during all redd surveys and effectively created a migration barrier (Figure 12). However, the entire L1 reach from the Okanogan River confluence to Loup Loup Falls $(3.3 \mathrm{~km})$ contained water during the first two surveys (Figure 12).

During our final survey on May 29, 2007, an additional 5 redds were observed (Figure 12). However, the reach downstream of the irrigation diversion dam for approximately $0.2 \mathrm{~km}$, where the most up-stream redds had previously been documented, was dewatered. The lack of water in the channel resulted in mortalities of post-emergent steelhead fry as well as other ages and species of fish (Figures 13 and 14). The reach from the irrigation return-flow channel downstream to Highway 7 still had minimal overland flow.

The observed redds represented approximately 18 summer steelhead, of which 2 would have been from natural origin. A redd density of 2.42 redds per kilometer was estimated for the accessible reach of Loup Loup Creek. Redd densities would likely increase substantially if perennial flows were reestablished, passage impediments were removed (culverts), and steelhead were supplemented using locally-adapted hatchery stocks. Steelhead redd surveys should continue in Loup Loup Creek to provide baseline information, and document the effectiveness of habitat rehabilitation projects, once implemented.

\section{Other small United States Tributaries}

As part of an ongoing effort to explore the more remote parts of the Okanogan subbasin, several small tributaries were surveyed in 2007. Redd counts were conducted on Chiliwist Creek, located south of Malott, on April 26; Elgin Creek, at the north end of Okanogan, on May 3; Fish Hatchery Creek, located at the southern end of Omak, on May 4; and Aeneas Creek, located south of Tonasket, on May 17. Access into these tributaries is typically limited due to alluvial fans and the high, vertical banks of the Okanogan River channel at their confluences. In 2007, due to the high water levels of the Okanogan River, these tributary confluences were inundated improving access for anadromous fish. All four of these small streams are spring fed and represent better rearing than spawning habitats. No redds or adult summer steelhead were observed during any of our surveys.

Although classified as a perennial waterbody, Elgin Creek was deemed inaccessible to steelhead due to a small falls identified near the confluence. Fish Hatchery Creek was also inaccessible to steelhead due to an undersized culvert and settling pond near the confluence with the Okanogan River. Chiliwist Creek, even when the Okanogan River is high enough to allow access, has minimal spawning potential for steelhead due to its narrow width (1.75m average) and limited discharge (typically less than $1 \mathrm{cfs}$ ). These conditions allow even small amounts of debris to impede both juvenile and adult 
steelhead passage. Aeneas Creek has very minimal spawning habitat due to elevated alkali levels and a compacted, “cement-like” substrate. Aeneas Creek could however, provide juvenile rearing habitat in the lower $0.5 \mathrm{~km}$ of the creek. Spawning habitat could be augmented by regularly depositing optimum size gravel and installing log structures to increase down-welling sites.

\section{Loup Loup Creek(L1) Redds 2007}

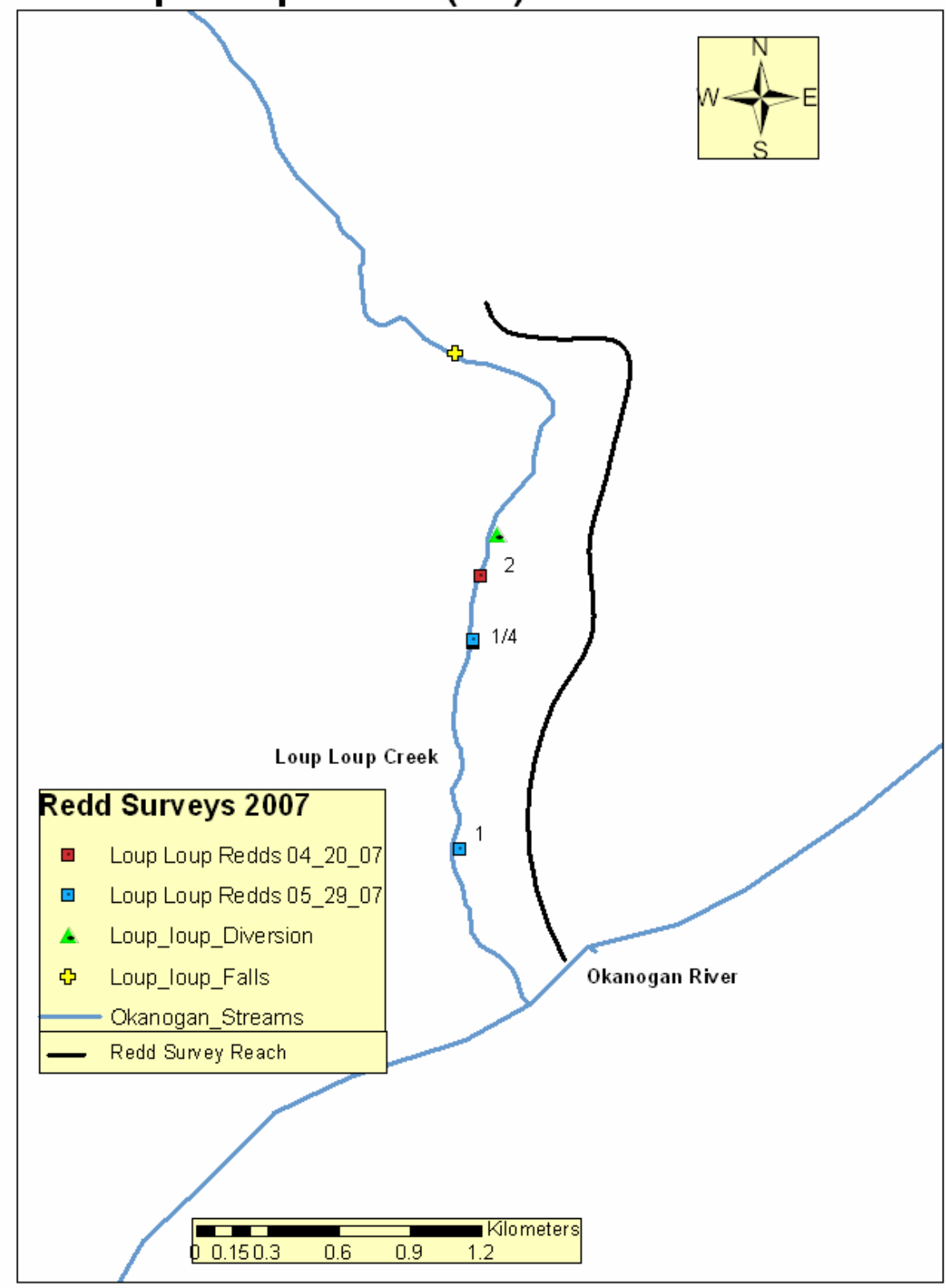

Figure 12: Steelhead redd distribution in Loup Loup Creek during 2007. The falls represent the natural upstream limit for anadromous fish. 

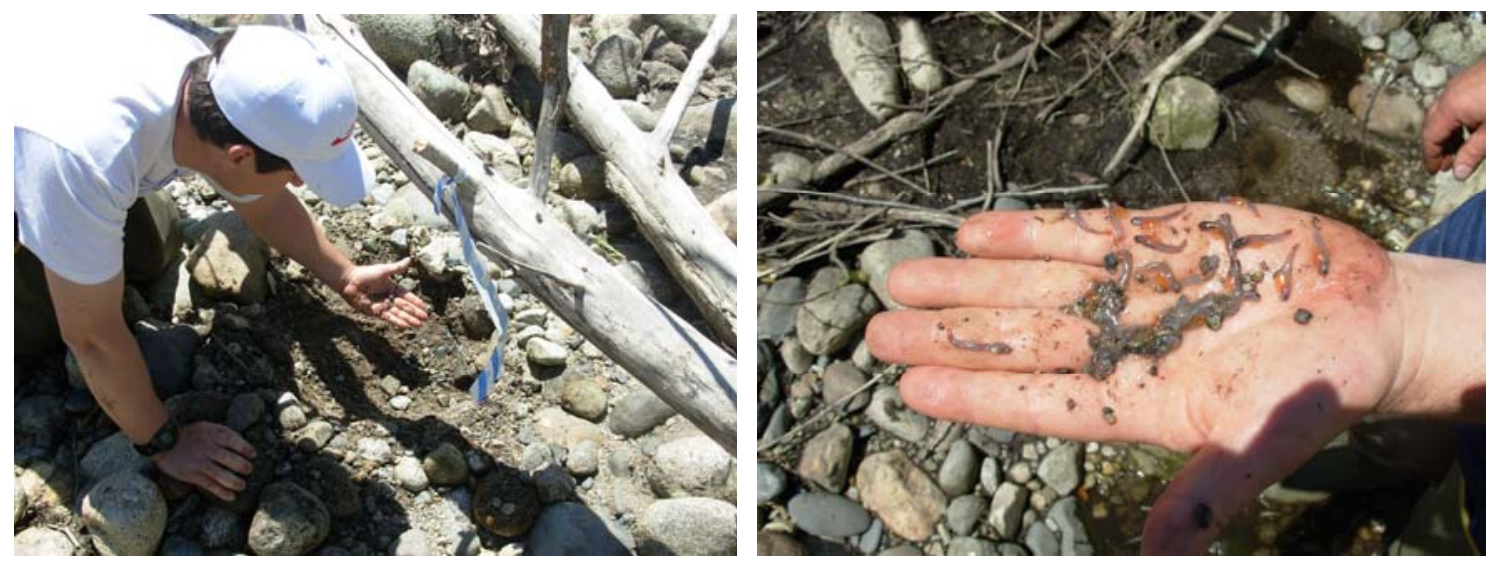

Figure 13: Left: Summer steelhead redd first observed during a survey conducted on April 20 became desiccated due to flow diversion on Loup Loup Creek on May 29. Right: Close-up of alevins removed from the redd showing that development was close to that of a swim-up fry.

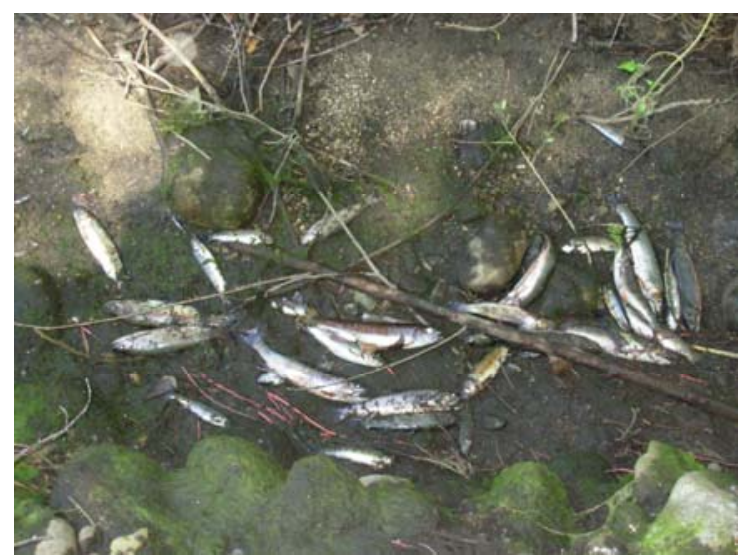

Figure 14: Multiple age-class mortalities of brook trout and rainbow trout observed during redd surveys conducted on Loup Loup Creek on May 29, 2007, showing multiple age classes of brook and rainbow trout that were killed by dewatering when an irrigation diversion dam, located at river kilometer 2.13 was closed..

\section{Escapement into Canada}

Since 2005, redd surveys have been conducted in Canada to compliment survey data collected in the United States. Although OBMEP data are very promising in the United States, results haven't been as impressive in Canada; a different method may be necessary to accurately calculate steelhead escapement into Canada. With the completion of the Zosel Dam counting station in 2006, a more accurate enumeration of summer steelhead entering Canada is possible. Therefore, OBMEP will utilize video counts at Zosel Dam, rather than redd surveys, to quantify the number of steelhead spawners entering Canada.

Calculating the number of spawners entering Canada is not as simple as counting the number of summer steelhead passing Zosel Dam (Table 5). The number of spawners that 
enter Ninemile (9) and Tonasket creeks (17),must be subtracted. These two creeks are located above Zosel Dam but south of the international border. In 2007, 147 summer steelhead were counted at Zosel Dam. Twenty six were estimated as destined for United States tributaries. Therefore, 121 summer steelhead were expected to spawn in the Canadian portion of the Okanagan Basin. Of the summer steelhead destined for Canada, an estimated 29 were naturally-produced; $23.7 \%$ of the total escapement.

Table 5. The number of spawning summer steelhead that passed Zosel Dam by month in 2007. Adipose-present fish are considered Wild; adipose-clipped fish are considered Hatchery.

\begin{tabular}{|ccc|c|}
\hline Month & $\begin{array}{c}\text { Number of Hatchery } \\
\text { Adults }\end{array}$ & Number of Wild Adults & Total \\
\hline March & 23 & 11 & 34 \\
April & 73 & 5 & 78 \\
May & 19 & 16 & 35 \\
\hline Total & 115 & 32 & 147 \\
\hline
\end{tabular}

\section{Canadian Distribution}

Spawner surveys in Canada have resulted in only a limited number of redds being observed over the last few years. This year was no exception as redd surveys conducted by the Okanagan Nation Alliance (ONA) between May 1 and June 19, 2007, indicate that redds were observed only in Inkaneep Creek, and only one fish seen in Vaseux Creek.(Figure 15). However, video counts at Zosel Dam, and trap catches on Inkaneep Creek in 2006, indicate a much greater number of adult summer steelhead entering Canada than accounted for by redd surveys. It seems unreliable to estimate spawner abundance using redd survey data collected in Canada, therefore estimates of adult escapement will be based upon Zosel Dam counts and trap counts, if installed. Spawner distribution estimates will be extrapolated from data collected from the three locations where summer steelhead redds have been observed during past redd surveys, and using historical redd survey and trap data.

From redd survey data collected in 2005, 2006, and 2007, the 2006 Inkaneep trap data (Long et al. 2006), fish observations in 2005 (Walsh and Long 2006), and anecdotal information compiled from local fisherman, we estimated $80 \%$ of summer steelhead entering Canada are destined for Inkaneep Creek. Approximately 17\% appear to enter Vaseux Creek and 3\% spawn along the main stem Okanagan River upstream of Osoyoos Lake. Using these percentages in conjunction with our pervious estimated escapement into Canada would result in an estimated escapement of 97 summer steelhead spawners into Inkameep Creek of which 23 would be of natural origin. We estimated that 21 steelhead spawned in Vaseux Creek, of which 5 would be of natural origin. Only 3 adult steelhead are estimated to have spawned in the main stem Okanagan River above Osoyoos Lake, including 1 fish that was likely of natural origin. 


\section{Inkaneep and Vaseux Creeks}

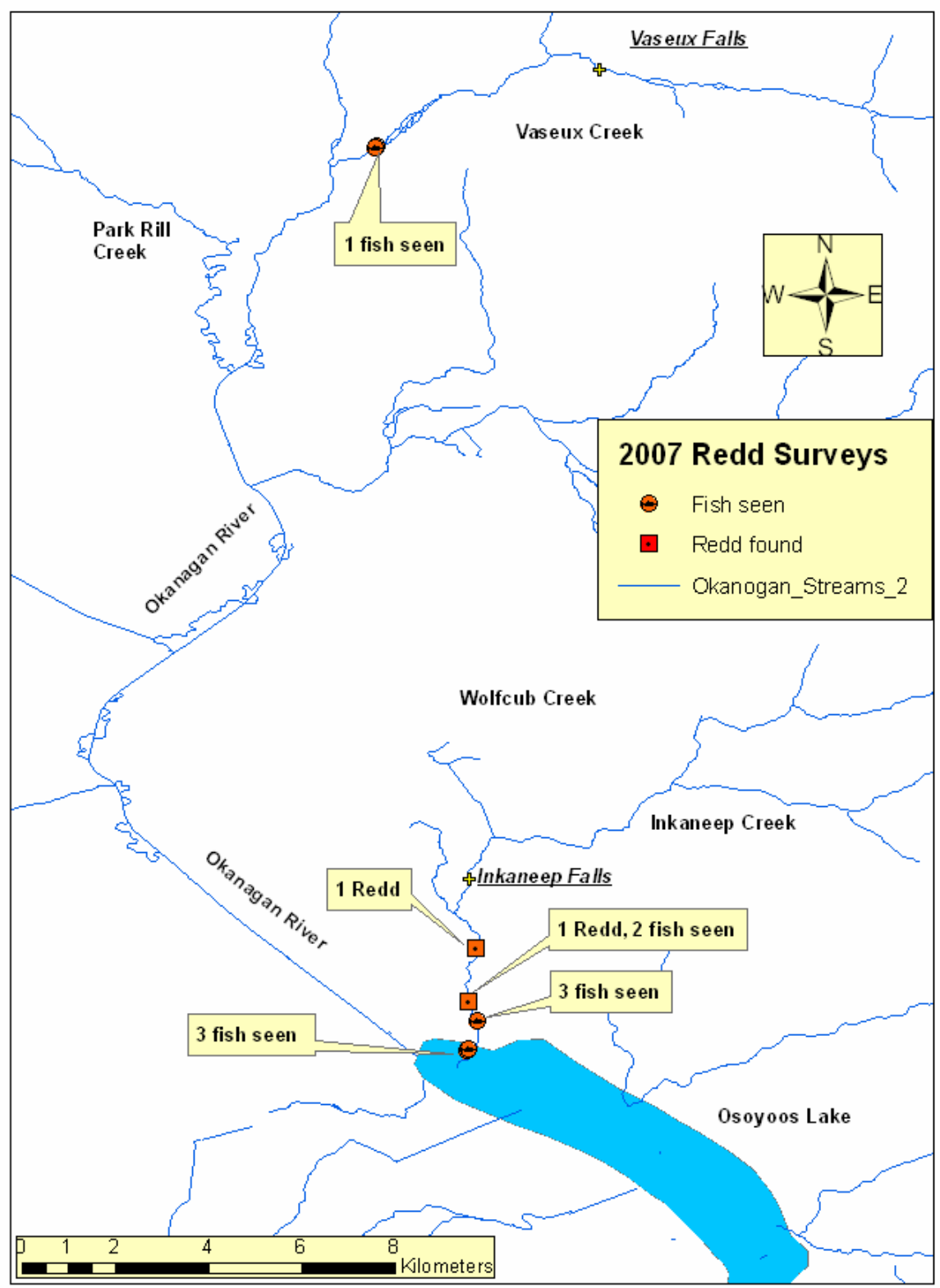

Figure 15: Steelhead and steelhead redds observed downstream of McIntyre Dam by the Okanagan Nation Alliance in the spring of 2007 using OBMEP survey protocols. 


\section{Bringing it all together}

Summer steelhead were recently relisted as "endangered" under the Endangered Species Act in the Upper Columbia River Evolutionary Significant Unit. Detailed, percent-wild information for 2007 has already been presented in this document and the mean value represents the best available information. High and low estimates represent the full range of possible values. The total escapement estimate for Okanogan River summer steelhead spawners in 2007 was between 1,234 and 1,280 (Table 6). These estimates are consistent with WDFW estimates derived from Wells Dam passage counts modified by subtracting harvest take information. WDFW estimated total spawner escapement into the Okanogan River Basin at 1,258 summer steelhead (Bob Jateff, WDFW, Pers. Comm.). All necessary information has been presented in order to provide a more accurate estimate of adult steelhead escapement and origin in the Okanogan Basin (Table 7).

A summary of the best available counts and estimates for each reach or sub-watershed throughout the Okanogan River basin is presented in Table 8. Our surveys indicate that main stem spawning is common throughout the Okanogan River but is more heavily focused in the northern portion of the Okanogan and lower Similkameen rivers. The lack of redds in the main stem Okanagan River in Canada is surprising as considerable, highquality habitat exists. Within the United States portion of the basin, most hatchery steelhead are scatter-planted at various locations along the Okanogan and Similkameen rivers; no hatchery stocking occurs in Canada. Therefore, it is highly likely that redd distributions are heavily influenced by the stocking locations used by Washington Department of Fish and Wildlife. Summer steelhead that spawn in tributary habitats of the Okanogan River are more likely to find suitable environmental conditions and rearing habitats than those spawning in the main stem. If more summer steelhead were stocked into Okanogan basin tributaries, the chances of these tributaries contributing to recovery efforts would be greatly enhanced. 
Table 6: Between year comparison of combined hatchery- and natural-origin summer steelhead for the Okanogan River. In 2005 and 2006, only low and high estimates were provided so that a simple arithmetic mean was computed for both years. The OBMEP estimate for 2007 was based on best available information provided in this document and presented in Table 8.

\begin{tabular}{|cc|ccc|}
\hline \multicolumn{4}{|c|}{ Okanogan River summer steelhead spawner population trend data } \\
\hline Year & WDFW escapement estimate & \multicolumn{4}{c|}{ OBMEP redd Survey estimate } \\
\hline & & Low & Mean & High \\
\hline 2005 & 1,322 & 1,147 & 1,315 & 1,482 \\
2006 & 811 & 779 & 855 & 930 \\
2007 & 1,258 & 1,234 & $1266^{*}$ & 1,280
\end{tabular}

* based upon all available information this is the best possible estimate

Table 7: Natural origin summer steelhead estimates since 2005 for the Okanogan River. The 2005 and 2006 estimates were calculated by multiplying the average wild percent for the Okanogan River from various sources, such as trap and dam counts with data from Table 6. The WDFW estimate is based upon Wells Dam counts and scale analysis. The OBMEP estimate for 2007 was based on best available information provided in this document and presented in Table 8.

\begin{tabular}{|cc|ccc|}
\hline \multicolumn{4}{|c|}{ Okanogan River wild summer steelhead spawner population trend data } \\
\cline { 1 - 2 } Year & WDFW escapement estimate & \multicolumn{4}{c|}{ OBMEP redd Survey estimate } \\
\hline & Low & Mean & High \\
\hline 2005 & N/A & 143 & 164 & 185 \\
2006 & 132 & 127 & 139 & 151 \\
2007 & 116 & 148 & $152^{*}$ & 155 \\
\hline
\end{tabular}

* based upon all available information this is the best possible estimate 
Table 8 - Redd counts and spawner counts for each sub-watershed or counting location along with the estimated number of naturally produced summer steelhead represented by each in 2007. The grand total for the entire Okanogan River population is presented with subtotals for tributary and main stem habitat types in the United States and Canada.

\begin{tabular}{|c|c|c|c|c|}
\hline Category & Description/location & $\begin{array}{c}2007 \\
\text { Spawners }\end{array}$ & Redd count & \# wild \\
\hline US Tributary & Spawners into Omak Weir & 97 & & 13 \\
\hline US Tributary & Spawners below Omak Weir & 55 & 25 & 7 \\
\hline US Tributary & Spawners into Bonaparte weir & 167 & & 21 \\
\hline US Tributary & Spawners below Bonaparte weir & 37 & 13 & 5 \\
\hline US Tributary & Spawners observed at Zosel Dam & 147 & & 32 \\
\hline US Tributary & Spawners into Salmon Creek & 46 & 21 & 6 \\
\hline US Tributary & Spawners into Wanacut Creek & 3 & 1 & 0 \\
\hline US Tributary & Spawners into Loup Loup Creek & 18 & 8 & 2 \\
\hline US Tributary & Spawners into Antoine Creek & 0 & 0 & 0 \\
\hline US Tributary & Spawners into Tonasket Creek & 17 & 6 & 2 \\
\hline US Tributary & Spawners to Ninemile Creek & 9 & 3 & 1 \\
\hline US Tributary & Spawners into Tunk Creek & N/D & N/D & N/A \\
\hline US Tributary & Spawners into Wildhorse Creek & 12 & 7 & 2 \\
\hline US Tributary & Spawners into Aeneas Creek & 0 & 0 & 0 \\
\hline US Tributary & Spawners into Whiskey Cache Creek & 0 & 0 & 0 \\
\hline US Tributary & Spawners into Chiliwist Creek & 0 & 0 & 0 \\
\hline US Tributary & Spawners into Elgin Creek & 0 & 0 & 0 \\
\hline US Tributary & Spawners into Fish Hatchery Creek & 0 & 0 & 0 \\
\hline US Tributary & Spawners into Pothole Canyon Creek & 0 & 0 & 0 \\
\hline US Tributary & Spawners into Swimptkin Canyon Creek & 0 & 0 & 0 \\
\hline Canada Tributary & Spawners into Inkaneep Creek & 97 & 56 & 23 \\
\hline Canada Tributary & Spawners into Vaseux Creek & 21 & 12 & 5 \\
\hline US Main stem & Spawners into reach $\mathrm{O} 1$ & 15 & 9 & 1 \\
\hline US Main stem & Spawners into reach $\mathrm{O} 2$ & 53 & 31 & 5 \\
\hline US Main stem & Spawners into reach $\mathrm{O} 3$ & 9 & 5 & 1 \\
\hline US Main stem & Spawners into reach $\mathrm{O} 4$ & 61 & 35 & 6 \\
\hline US Main stem & Spawners into reach $\mathrm{O5}$ & 91 & 53 & 8 \\
\hline US Main stem & Spawners into reach 06 & 18 & 10 & 2 \\
\hline US Main stem & Spawners into reach $\mathrm{O} 7$ & 258 & 150 & 24 \\
\hline US Main stem & Spawners into reach SI & 181 & 105 & 17 \\
\hline Canada Main stem & Spawners into Canadian main stem & 3 & 2 & 1 \\
\hline Subtotals & Adult escapement into US Main stem & 684 & 398 & 63 \\
\hline Subtotals & Adult escapement into US Tributaries & 461 & 84 & 60 \\
\hline Subtotals & Adult Escapement into Canada & 121 & 70 & 29 \\
\hline Grand total & & 1,266 & 552 & 152 \\
\hline
\end{tabular}




\section{Conclusions}

Steelhead spawner data clearly show that redd surveys throughout the United States portion of the Okanogan River Basin are possible in both tributary and main stem habitats and the distribution of spawning can be effectively quantified. Baseline information for spawning habitat distribution, spawn timing, and spawner escapement have been determined, but additional, annual data are necessary to strengthen the body of information for use in trend analysis. High quality spawning Okanogan River basin also allow for accurate estimates of redd production and spawner escapements even in years when environmental conditions prevent collection of adequate field data. Spring spawner data provides a reliable estimate of adult escapement and slightly less reliable estimate of origin for returning adults. Dependable and reliable estimates such as these are critical for tracking recovery of endangered upper Columbia summer steelhead within the Okanogan River basin.

The use of picket weir traps, video counting chambers, radio telemetry, or simple estimate models have produced more dependable data in Canada than redd surveys alone. Less that 30 redds in total have been identified in 3 years. Therefore the ONA and Colville Tribes need to consult with the upper Columbia Regional Technical Team, Pacific Northwest Aquatic Monitoring Partnership, Columbia System wide Monitoring and Evaluation Project, and Bilateral Okanagan Basin Technical Working Group on how best to collect summer steelhead spawner distribution and escapement estimates. The highly dynamic nature and flashy discharges of streams in southern British Columbia make this a difficult location for conducting redd surveys. Spawner distribution data collected during 2007 is capable of providing a dependable escapement estimate for the U.S. portion of the Okanogan River sub-basin and should continue unabated while the proper approach for assessing changes in steelhead distribution over time are debated for the portion of the basin located within Canada.

Annual variations in redd distribution can be profound for small tributaries within the Okanogan River basin. Changes in spawner distributions are primarily driven by four factors:

1) The discharge and elevation of the Okanogan River;

2) The discharge of the tributary streams;

3) The timing of runoff that alters the shape of the hydrograph, and most importantly;

4) The stocking location of hatchery smolts.

The first three items are largely part of the natural environmental conditions present in the basin, although they can be altered dramatically by such things as dam releases, irrigation withdrawals, and climate change. These items are inherently difficult for fisheries managers to address. However, the choice of juvenile stocking locations is well within the jurisdiction of fisheries managers to change or modify for the benefit of a given stock. Within the Okanogan River basin more effort should be given toward developing locally-adapted summer steelhead broodstocks and stocking into tributary habitats that provide the most suitable environmental and rearing conditions. 


\section{Literature Cited}

Arterburn, J.E., and K. Kistler 2006. 2006 Okanogan Basin Steelhead Spawning

Surveys. 2006 Report for Bonneville Power Administration project \#200302200.

Colville Confederated Tribes Fish and Wildlife Department. Nespelem, WA.

Arterburn, J.E., K. Kistler and C. Fisher 2007a. Anadromous Fish Passage Barriers in the Okanogan Basin. Report\# CCT/AF-2007-1 for the Colville Tribes. Colville Confederated Tribes Fish and Wildlife Department. Nespelem, WA.

Arterburn, J.E., K. Kistler and P. Wagner 2007b. Okanogan Basin Monitoring and Evaluation Program Field Manual Redd Survey Methodology Final Draft March 7, 2007. http://nrd.colvilletribes.com/obmep/pdfs/Redd\%20survey\%20protocol.pdf Colville Confederated Tribes Fish and Wildlife Department. Nespelem, WA.

Arterburn, J.E., K. Kistler and R. Dasher 2005. 2005 Okanogan Basin Steelhead Spawning Ground Surveys. 2005 Report for Bonneville Power Administration project \#200302200. Colville Confederated Tribes Fish and Wildlife Department. Nespelem, WA.

Arterburn, J.E., and C.J. Fisher 2003. Steelhead surveys in Omak Creek. 2003 Annual Report for Bonneville Power Administration project \#2000-001-00 and NOAA Fisheries - Pacific Coastal Salmon Recovery Fund, November 2003. Colville Confederated Tribes Fish and Wildlife Department. Nespelem, WA.

Arterburn, J.E., and C.J. Fisher 2005. Steelhead surveys in Omak Creek. 2004 Annual Report for Bonneville Power Administration project \#2000-001-00 and NOAA Fisheries - Pacific Coastal Salmon Recovery Fund, April 2005. Colville Confederated Tribes Fish and Wildlife Department. Nespelem, WA.

Fisher, C.J., and J.E. Arterburn. 2003. Steelhead surveys in Omak Creek. 2002 Annual Report for Bonneville Power Administration project \#2000-001-00 April 2003. Colville Confederated Tribes Fish and Wildlife Department. Nespelem, WA.

Hillman, T.W. 2004. Monitoring strategy for the Upper Columbia Basin. Prepared for: Upper Columbia Regional Technical Team, Upper Columbia Salmon Recovery Board, Wenatchee, Washington.

Kistler, K., and J. Arterburn 2007. 2006 Okanogan Basin Snorkel Surveys. BPA project \#200302200. Colville Confederated Tribes Fish and Wildlife Department. Nespelem, WA.

Kistler, K., J. Arterburn, and M. Rayton. 2006. 2005 Okanogan Basin Snorkel Surveys. BPA project \#200302200. Colville Confederated Tribes Fish and Wildlife Department. Nespelem, WA. 
Long, K., M. Squakin, and C. Louie 2006. Steelhead spawner enumeration in the Okanogan Mainstem and tributaries: Inkaneep, Vaseux and Shuttleworth creeks2006. Prepared by the Okanagan Nation Alliance Fisheries Department, Westbank, BC.

Smith A.K. 1973. Development and application of spawning velocity and depth criteria for Oregon salmonids. Transactions of the American Fisheries Society 102:312316

Walsh, M. and K. Long. 2006. Okanogan Basin Monitoring and Evaluation Program (OBMEP) 2005 Annual Report for Sites in Canada. Prepared by the Okanagan Nation Alliance Fisheries Department, Westbank, BC.

WSRFB (Washington Salmon Recovery Funding Board). 2003. Draft 5/16/2003 monitoring and evaluation strategy for habitat restoration and acquisition projects. Washington Salmon Recovery Funding Board, Olympia, WA. Web link: http://www.iac.wa.gov/srfb/docs.htm 